\title{
ENTRE EL MITO Y LA MEMORIA. IMÁGENES DE UNA GUERRA
}

\author{
Pedro Payá López
}

Hablar de mito y memoria nos obliga a hacer una primera precisión conceptual. El mito es entendido aquí, según la formulación griega, como una forma de discurso contraria al Logos y, por lo tanto, construcción irracional de una verdad cuya esencia es su propia manifestación y rotundidad, el ser dicho; esto es, una verdad sin posibilidad de ser contrastada, un discurso que no resiste la crítica ${ }^{1}$. Por lo tanto, la forja del mito (de la Guerra Civil) debemos relacionarla con una forma de simplificación del discurso con el que, convertido en propaganda por el nuevo Estado franquista (lo que dijo de sí mismo), trató de justificarse mediante una sacralización de sus orígenes. La memoria, en cambio (como recuerdo público), debe someterse a la fidelidad del pasado y su utilidad en el presente; esto es, contribuir a formar una identidad cuyos valores y principios sean sometidos a la razón y el debate crítico ${ }^{2}$. Si la función y característica que define a los mitos contemporáneos es su utilización racional por el poder político (Cassirer) ${ }^{3}$, la función de una cultura de la memoria es, en cambio, rescatar del olvido, reparar (administrar su legado y hacer justicia) a quienes sufrieron o fueron víctimas de la violencia ejercida en el pasado 4 .

1. LLEDÓ, Emilio, El silencio de la escritura, Madrid, Espasa-Calpe, 1998, edición corregida y aumentada. Así, el mito no produce memoria sino olvido, ya que la función del lenguaje mítico no es la de ser proferido para provocar diálogo (base de la intersubjetividad en la que edificamos la memoria que somos) sino sumisión y silencio. Ver, del mismo autor, El surco del tiempo, Barcelona, Crítica, 1992 y La memoria del Logos, Madrid, Taurus, 1996.

2. Todorov, Tzvetan, Los abusos de la memoria, Barcelona, Paidós, 2000.

3. Ver su clásico trabajo donde estudia la función política del mito en el siglo XX, CASSIRER, Ernst, El mito del estado, México, Fondo de Cultura Económica, 1947.

4. Cada generación adquiere el legado de la memoria histórica, que debe administrar, convirtiéndose en responsable de la reparación. Al mismo tiempo, si la reparación nos recuerda las injusticias cometidas en el pasado, la única justicia que les queda a las víctimas es la del reconocimiento de lo que fue negado. Hay que recordar que cada crimen cometido es ocultado en el pasado, sea por medio de subterfugios legales, como por el interés planificado de hacer desaparecer a los tes- 
Por otra parte, hablar de las «imágenes de una guerra» y, además, procurar hacerlo "desde la perspectiva actual»-objetivo del seminario en el que tiene origen este artículo- me lleva a hacer una constatación de partida: Debemos concebir estas imágenes, filmadas en distintos momentos y coyunturas, como depósitos de memoria que ahora nos llegan para que los interpretemos buscando una nueva mirada sobre el pasado del que hablan y el presente que nos muestran ${ }^{5}$.

No por ello haremos un repaso por toda la filmografía de la Guerra Civil, más bien prestaremos atención a cuál ha sido el papel de las imágenes (cinematográficas) en la formación de la imagen (mental) de la Guerra Civil española durante los últimos setenta años o, lo que es lo mismo, cómo estas imágenes han pasado del mito a la memoria ${ }^{6}$.

Escribir sobre los cambios y permanencias producidos en este período de setenta años nos lleva a hacer una última consideración. La II República y la Guerra Civil suponen un punto de referencia en la formación de la memoria de tres generaciones de españoles que conviven en la actualidad: La de los testigos, cercana a su desaparición, la de los "hijos de la guerra», que protagonizaron la transición democrática, y la de los nietos, ajenos al pacto de silencio y olvido que tácitamente se produjo durante la misma, en base a una supuesta inconveniencia de mirar al pasado. Una generación que está impulsando la recuperación de la memoria de las víctimas del franquismo, reclamando su legítima reparación ${ }^{7}$.

Atendiendo a este aspecto generacional, podemos distinguir tres períodos en la construcción de la memoria cinematográfica de la Guerra Civil: El primero es el que hemos denominado como el de los testigos, que comprende las producciones realizadas en ambos bandos durante el conflicto bélico, además de las llevadas a cabo durante cuarenta años de dictadura. En este período el cine fue utilizado como uno de los instrumentos de propaganda con los que el régimen de Franco se auto-representó, recurriendo a unos mitos que trataron de legitimar su origen y permanencia en el poder. Fueron años, por otra parte, en los que la propaganda sólo era el corolario a la represión y la censura permanen-

tigos y vestigios del crimen, caso extremo del genocidio judío. Al ser responsable de la memoria heredada, cada generación se convierte, en este sentido, en administradora de justicia. Ver MATE, Reyes, Por los campos de exterminio, Barcelona, Anthropos, 2003.

5. Este texto tiene su origen en la conferencia presentada en el curso realizado en la Universidad de Verano Rafael Altamira (Universidad de Alicante), con el título La II República y la Guerra Civil desde la perspectiva actual, celebrado en Alicante entre el 17 y el 21 de julio de 2006.

6. Ver el excelente trabajo de SÁnCHEZ-BIOSCA, Vicente, Cine y guerra civil española. Del mito a la memoria, Madrid, Alianza Editorial, 2006.

7. ARÓSTEGUI, Julio, "Traumas colectivos y memorias generacionales: el caso de la guerra civil», en Aróstegui, Julio y Godicheau, François (eds.), Guerra Civil. Mito y memoria, Madrid, Marcial Pons/Casa Velásquez, 2006, pp. 57-92 y ARÓsteGuI, Julio (ed.), España en la memoria de tres generaciones. De la esperanza a la reparación, Madrid, Fundación F. Largo Caballero/Editorial Complutense, 2007. 
tes durante toda la dictadura ${ }^{8}$. No debemos olvidar que aunque el Nuevo Estado trató de convencer a una parte de la población, se sustentó fundamentalmente en la violencia política?.

Se trata de un periodo para el que es más adecuado hablar de subversión que de construcción de la memoria del conflicto, ya que se intentó plasmar una memoria oficial sobre el silencio de una parte, constituyendo «lugares de memoria» que en realidad eran de desmemoria, de olvido ${ }^{10}$. En este sentido, la subversión de la memoria se produjo mediante la realización del mito, cuya función -como escribiera Roland Barthes- no es hacer desaparecer la realidad, sino deformarla ${ }^{11}$. Ésta es la naturaleza última de los mitos de la Guerra Civil construidos durante el franquismo. Como ha afirmado Xavier Antich, el olvido es doble cuando en el lugar de aquello que se borra se inscribe otro relato ${ }^{12}$.

Un segundo momento de construcción de la memoria de la Guerra Civil fue el protagonizado por los «hijos de la guerra", generación que llevó a cabo la transición política. Esta etapa, que abarca las producciones realizadas desde el tardo-franquismo hasta la década de los ochenta, tuvo su orígen en el cambio cultural que se produjo bajo la dictadura en la década de los sesenta y que, en lo que a la producción cinematográfica se refiere, su manifestación más concreta fue lo que se denominó «Nuevo Cine Español». En el mismo debemos inscribir a cineastas como Carlos Saura, Jaime Camino, Basilio Martín Patino o Víctor Erice. La película paradigmática de este «momento generacional» fue $L a$ caza, de Carlos Saura (1965), parábola sobre la contienda que por primera vez -aunque indirectamente- hablaba del conflicto al margen del discurso oficial, que fue el único permitido durante toda la dictadura.

Hay en esta película, como veremos, una pregunta clave. En un momento dado, cuando sale a colación la guerra, un adolescente, Enrique (Emilio Gutiérrez Cava), representante de una generación que no ha vivido de primera mano

8. La estrecha relación entre represión, censura y propaganda en la política cinematográfica del franquismo ha sido puesta de relieve por DíEz PUERTAS, Emeterio, El montaje del franquismo. La politica cinematográfica de las fuerzas sublevadas, Barcelona, Laerter, 2002.

9. Puede verse una aproximación en este sentido en los trabajos de CENARRo LAGUNAS, Ángela, "Muerte y subordinación en la España franquista: el imperio de la violencia como base del «nuevo Estado»", Historia Social, n. ${ }^{\circ} 30$ (1998), pp. 5-22. JuliÁ, Santos (coord.), Víctimas de la guerra civil, Madrid, Temas de Hoy, 1999. RICHARDS, Michael, "Guerra civil, violencia y la construcción del franquismo", en PRESTON, Paul (ed.), La república asesinada. Hostilidad internacional y conflictos internos durante la guerra civil, Barcelona, Península, 1999. CASANOVA, Julián (coord.), Morir, matar sobrevivir. La violencia en la dictadura de Franco, Barcelona, Crítica, 2002.

10. En la denominación que hace VIÑAS, Ángel, «Franco o la subversión de la memoria», en ARÓsTEGUI, Julio (ed.), España en la memoria de tres generaciones, op. cit., pp. 100-119.

11. BARTHES, Roland, Mitologías, México, 1986, 6. ${ }^{2}$ ed., citado por REIG TAPIA, Alberto, "Los mitos políticos ranquistas de la guerra civil y su función: el «espíritu» del 18 de julio de 1936», en Aróstegui, Julio y Godicheau, François (eds.), Guerra Civil. Mito y memoria, op. cit., pp. 201244, p. 201.

12. En ANTICH, Xavier, Lledó, Emilio, RidaO, José María y Semprún, Jorge, «La necesidad de la memoria», Letras Libres, diciembre de 2003, pp. 41-45. 
el conflicto, pregunta ¿qué guerra ?13 $^{13}$ Esta pregunta -que en realidad trataba de cuestionar la historia oficial- se proyectará a lo largo del cine del tardofranquismo y la transición, cuando los intentos de recuperar la memoria se vean truncados por la falta de comunicación intergeneracional, tal como ocurre en La prima angélica, también de Saura (1973), o en las dos obras de Víctor Erice El espiritu de la colmena (1973) y El sur (1983), como veremos detenidamente. Hay que tener en cuenta que esta nueva generación, más que recuperar su memoria (experiencia), lo que pretendía era tener acceso a una memoria (histórica) postergada.

Finalmente, quiero destacar un tercer momento en la construcción de la memoria de la Guerra Civil en relación a la generación de los «nietos de la guerra», generación que está impulsando la recuperación de la memoria histórica al reivindicar la necesaria reparación de las víctimas del franquismo, que todavía siguen enterradas en cunetas y fosas comunes. La realización de la película Tierra y Libertad (Land and Freedom, 1995) por el británico Ken Loach supone un punto de no retorno, en este sentido. Tierra y Libertad, y el debate que originó dentro del gran público y al que no fue ajeno el mundo académico, coincidió con el despertar de una toma decidida de conciencia respecto a la necesidad de mirar al pasado y recuperar la memoria ${ }^{14}$. Precisamente, la película de Loach comienza en el momento presente, cuando una joven, que asiste al entierro de su abuelo, encuentra en una maleta varios recortes de periódicos, cartas de amor y un puñado de tierra traído de España. Son objetos que la hacen adentrarse, por medio de un flashback, en la recuperación de la memoria de su abuelo, cuando vino como voluntario a luchar en la Guerra Civil, ingresando en las milicias del POUM. Sin duda, este camino abierto por Tierra y Libertad en cuanto al diálogo intergeneracional tiene su punto culminante en la obra de David Trueba Soldados de Salamina (2003), adaptación de la novela de Javier Cercas en la que el hilo conductor de la trama vuelve a ser la recuperación de la memoria por la generación de los nietos. Se trata, además, de una recuperación de la memoria en la que los protagonistas políticos han dejado paso a los personajes anónimos ${ }^{15}$.

13. En estos mismos años otra pregunta sirve para hacer una denuncia similar desde el cine italiano: El olvido de la experiencia fascista y la resistencia. Se trata del film de Luciano Salce La Voglia matta (1962), en el que, en un momento dado, la protagonista pregunta: «Mussolini? Chi? Il padre de la pianista?». Ver, en este sentido, los comentarios de BRUNETTA, Gian Piero, Cent'anni di cinema italiano, vol. 2, dal 1945 ai giorni nostri, Roma, Laterza, 2004, nuova edizione aggiornata, p. 187.

14. Puede seguirse el debate mantenido en cinco números consecutivos de la revista L'Avenç, (204 a 208) correspondientes a los meses de junio a octubre de 1996. Intervinieron, en este orden, Paloma Aguilar, Víctor Alba, Gabriel Jackson, José Álvarez Junco, Santos Juliá, Pelai Pagès, Andy Durgan, de nuevo Paloma Aguilar y Miquel Izard. En el mismo se hacen referencias tanto a Tierra y Libertad como a Libertarias (1996) de Vicente Aranda. Una recopilación de la opinión pública recogida en la prensa diaria respecto a esta última película en Film-Historia, vol. VI, n. ${ }^{\circ}$ 3 (1996), pp. 300-309.

15. Al contrario de ejemplos anteriores como La vieja memoria (1977) de Jaime Camino y Por qué perdimos la guerra (1978) de Diego Santillán y Luis Galindo, que dan cuenta de los intentos de 
Más allá de las críticas que se realizaron a Tierra y Libertad respecto a su excesivo romanticismo y el maniqueísmo con el que trataba un tema sin duda complejo, su llamada de atención respecto a la necesidad de recuperar la memoria es lo que ahora destacamos. Y esto es así porque Tierra y Libertad debemos enmarcarla en unos años -además del sesenta aniversario de la Guerra Civil-en los que se estuvo hablando del supuesto fin de la historia y las ideologías ${ }^{16}$. Son años en los que la Europa de la gran velocidad y los criterios macroeconómicos de convergencia de Maastrich contrasta -se ve desgarrada- por otra realidad que conmocionó y sigue conmocionando a los europeos ${ }^{17}$, además de constituir un lugar de reflexión privilegiado sobre Europa, el siglo XX y el papel ético del cine como vehículo de compromiso intelectual, tal como ha demostrado recientemente Jean Luc Godard con su Notre musique (2004) ${ }^{18}$. Me refiero a la guerra civil (de nuevo una guerra civil sacudía Europa) de la ex-Yugoslavia, concretamente la guerra de Bosnia. A la vez que Loach llamaba la atención sobre la necesidad de utopía y sobre la importancia de las ideologías, Emir Kusturica (Underground) y Theo Angelopuolos (La mirada de Ulises) se acercaban a la guerra de Bosnia para reflexionar sobre la Europa del siglo XX como siglo de barbarie y conflictos colectivos concluyendo -en las últimas palabras de ambas películas- que «la historia no tiene fin».

recuperar la memoria realizados tras la muerte del dictador, en los que, en los umbrales del proceso de transición política, se privilegiaba el testimonio de los protagonistas políticos.

16. Ver, en este sentido, los comentarios de CÉSAR, Samuel, R., "La utopía es necesaria", Dirigido por..., n. ${ }^{\circ} 235$, mayo de 1995, p. 23.

17. El pasado mes de marzo de 2007 el Tribunal Penal Internacional de Justicia para la ex Yugoslavia calificó como genocidio la matanza de 8.000 musulmanes llevada a cabo por las fuerzas militares y paramilitares serbobosnias en la ciudad bosnia de Srebrenica. La matanza se realizó entre el 13 y el 15 de julio de 1995 ante la pasividad de los cascos azules de la ONU, que supuestamente protegían la zona. Desde el punto de vista de la memoria, es de obligada consulta el testimonio de un superviviente: Emir Suljagic. En él encontramos la figura del testigo según la concibe Jorge Semprún, como quien ha vivido y sufrido los acontecimientos y, por lo tanto, con capacidad de hacer del lector también un "testigo», sensación que, sin duda, nos traslada la extraordinaria obra de SULJAGIC, Emir, Postales desde la tumba, Barcelona, Galaxia Gutenberg/ Círculo de Lectores, 2007. Sobre los genocidios en el siglo XX ver la obra de BRUNETEAU, Bernard, El siglo de los genocidios, Madrid, Alianza, 2006 y Gellately, Robert \& KIERNAN, Ben, The specter of Genocide. Mass Munder in Historical Perspectiva, Cambridge University Press, 2003.

18. Debemos destacar también un cortometraje menos conocido del autor, que supuso su primera incursión en la guerra de Bosnia. Se trata de Je vous salue Sarajevo (1993), en el que el cineasta suizo diserta, a la vez que nos muestra diversos planos de una fotografía de guerra, sobre el papel de la cultura y el arte, acompañado del Silouan's Song de Arco Pärt. En la imagen observamos un pequeño grupo de militares, que mantienen retenidas a unas prisioneras boca abajo contra el suelo. Mientras tanto, uno de ellos, a la vez que fuma un cigarrillo se dispone a patear la cabeza de una de las víctimas, tal como vemos en el último plano, cuando la fotografía nos es mostrada en su conjunto. Estamos ante la escenificación de la absoluta banalización de la violencia, llevada magistralemente a la síntesis. Una violencia gratuita que el cineasta suizo -entiende-, forma parte de la "cultura de la barbarie» del siglo XX. Así, tras reflexionar sobre la cultura, a la que califica como la norma, y el arte, al que define como la excepción, se pregunta -sobre los interminables planos de la citada imagen- si acaso el cometido de la cultura europea no será «destruir el arte de vivir, que todavía florece». 
Son años, mediados de los noventa, en los que otro cineasta -Gianni Amelio-, último representante de la tradición neorrealista italiana, nos dice con su desgarradora Lamerica (1994) que la falta de memoria es una forma de muerte, la de la no conciencia y, por lo tanto, la de la no identidad. Esa Italia que no sólo ha abandonado a sus hijos, sino -lo que es peor-olvidado a sus padres, resonando los ecos de aquella extraordinaria poesía de Pier Paolo Pasolini Io sono una forza del passato... mostruoso è chi è nato delle viscere de una dona morta ${ }^{19}$.

Por ello, insisto, la lectura e importancia de Tierra y Libertad debemos hacerla dentro de este panorama europeo de toma de conciencia con respecto a la necesidad de recuperar la memoria en clave de aprendizaje colectivo ${ }^{20}$.

Una última consideración con respecto al papel central que ocupa la recuperación de la memoria en nuestra cultura contemporánea. En paralelo a la representación cinematográfica de la Guerra Civil y el franquismo, sin duda experiencias que suponen el elemento central del siglo XX español, la representación cinematográfica del que es el acontecimiento central del siglo XX para la cultura occidental -la Segunda Guerra Mundial- ha sufrido, de la misma forma, una evolución generacional que, a grandes rasgos, podemos decir que ha pasado de la exaltación de los héroes de la resistencia a la memoria de las víctimas anónimas. De esta forma, el genocidio del pueblo judío ha pasado a ocupar un primer plano en la representación cinematográfica de la Segunda Guerra Mundial, en detrimento de los deportados políticos o la lucha contra el fascismo. De ahí que estas representaciones cinematográficas, en palabras de Enzo Traverso, hayan sufrido una cierta despolitización en beneficio de la memoria de las víctimas ${ }^{21}$.

Algo paralelo ha ocurrido en las representaciones cinematográficas de la contienda española, salvando la posición de Tierra y Libertad mencionada y que la debemos enmarcar dentro de la propia trayectoria seguida por un cineasta tan particular como Ken Loach, con un compromiso social y político que está patente en todas sus realizaciones ${ }^{22}$. De esta forma, podemos decir que en las

19. PASOLINI, Pier Paolo, Poesia in forma di rosa (1961-1964), Garzanti, 1976, p. 22.

20. Éste es el objetivo que, desde los poderes públicos, debería presidir un decidido impulso por la recuperación de la memoria histórica. Unas políticas de la memoria que faciliten el aprendizaje colectivo mediante un recuerdo público que persiga tanto la justa reparación de las víctimas como la formación de una conciencia pública basada en valores morales y principios democráticos sometidos al examen de la razón y la crítica. La futura ley de memoria histórica debería estar presidida por esta combinación de memoria y justicia que es, para Todorov, lo que permite el aprendizaje, la ejemplaridad. Lo contrario sería caer en lo que este mismo autor califica como los dos abusos de la memoria: sacralización o aislamiento radical del recuerdo y banalización o asimilación abusiva del presente en el pasado. Ambos casos suponen una esterilización de la memoria, que queda incapacitada para ejercer su función pública de aprendizaje y ejemplaridad. Ver TODOROV, Tzvetan, Memoria del mal, tentación del bien. Indagación sobre el siglo XX, Península, 2001 y Los abusos de la memoria, Barcelona, Paidós, 2000.

21. Traverso, Enzo, "La vita è bella? Roberto Benigni e Auschwitz», Passato e presente, XVII, n. ${ }^{\circ} 48$ (1999), pp. 13-22.

22. Podemos decir que junto al finlandés Aki Kaurismäki, Ken Loach representa el ala más radical del cine social europeo. Riff, Raff (1990), Lloviendo piedras (Raining stones, 1993), Ladybird, Ladybird 
representaciones de la Guerra Civil hemos pasado, a grandes rasgos y en paralelo al conflicto mundial, de la memoria (representación mítica) de «la victoria» bajo un régimen de dictadura, a la recuperación de la memoria de las víctimas anónimas, como ocurre en Soldados de Salamina. Vayamos por partes.

Antes de adentrarnos en las características principales de cada uno de los períodos mencionados, debemos atender dos cuestiones, desde un punto de vista metodológico, respecto a la consideración de las relaciones entre cine e historia. La primera se refiere a la utilización del cine como fuente histórica, ya que el material audiovisual generado en el siglo XX supone un capital cultural del que no debe prescindir la historiografía. Las representaciones cinematográficas son parte imprescindible de la memoria visual del siglo XX y lo son en un doble sentido, ya que ofrecen la posibilidad de acercarnos a dos épocas diferentes: El período narrado y el momento histórico en el que fueron realizadas. Solamente si tenemos en cuenta este doble valor del documento cinematográfico podremos profundizar en la verdadera relación entre cine e historia y recorrer las dos líneas que en su momento trazara Marc Ferro: «lectura histórica del cine» y "lectura cinematográfica de la historia», entendiendo por la primera la posibilidad de indagar en la sociedad que ha producido y recibido los filmes y, por la segunda, la capacidad del cine para poner en escena, para narrar cinematográficamente, los acontecimientos del pasado ${ }^{23}$. Por ello, la mayoría de estas imágenes nos hablan más que de la Guerra Civil (que también) de la interpretación y representación que de la misma se ha hecho en los últimos setenta años.

En segundo lugar, defendemos la falta de distinción entre el documental y la ficción con respecto a la representación de lo real. Hay que tener en cuenta que el cine documental no supone una mayor dosis de realidad o de verdad que el cine de ficción, ya que lo documental y la ficción están presentes en el propio carácter discursivo del cine. El cine documental, que también es ficción, es reconstrucción, es representación subjetiva de la realidad, pues utiliza el montaje como forma subjetiva de discurso. Pero, además del montaje, también la voz en off le puede dar un sentido u otro a unas mismas imágenes, como nos demostrara Chris Marker en sus Cartas desde Siberia. Este aspecto es especialmente reseñable en las películas de montaje de la Guerra Civil, ya que muchas de las imágenes rodadas durante el conflicto bélico fueron utilizadas por los dos bandos. En este sentido, la propaganda franquista supo beneficiarse del numeroso material rodado en la zona republicana para estructurar un discurso en el que se contraponían el orden y la justicia imperantes en la "España nacional», con las imágenes de desorden y salvajismo (profanaciones, saqueos, ejecuciones, cadáveres) «consentidas y alentadas» por el Gobierno republicano.

(1994), La canción de Carla (Carlas's song 1996), May name is Joe (1998), Pan y rosas (Bread and roses, 2000), Sólo un beso (Ae Fond Kiss, 2004) y su última película, galardonada con la Palma de Oro en el Festival de Cannes, The wind that shakes the barley (El viento que sacude la cebada, 2006), son muestra de ello.

23. FERRO, Marc, Cine e historia contemporánea, Barcelona, Ariel, 1995. 


\section{LA FORJA DE LOS MITOS. LAS PRODUCCIONES DURANTE EL PERÍODO BÉLICO Y LA DICTADURA}

Aunque ambos bandos fueron conscientes de la importancia del cine como medio de propaganda y así lo utilizaron, una clara línea dicotómica divide la forma de representar la contienda en ambas producciones. Mientras el bando rebelde se centró en un discurso heroico que exaltaba la mística de la guerra como liberación, el republicano lo hizo en el compromiso ético-político y la defensa de valores universales como la libertad y la solidaridad. Sea como fuere, ambas representaciones de la contienda civil dan cuenta de la construcción de un discurso legitimador y tuvieron como objetivo convencer a la comunidad internacional de sus razones en la lucha. Mientras la producción franquista se centra en el supuesto caos en el que se veía envuelta la República como causa de una guerra inevitable y la necesidad de la rebelión ante el peligro comunista que avanza, la republicana denuncia la barbarie de una "guerra total» provocada por un ejército levantado en armas contra su pueblo. Mientras el bando rebelde enfatiza la importancia de la ayuda de la URSS y las Brigadas Internacionales, denunciando la sovietización del bando republicano, éste insiste en lo nefasto que resultaron las políticas del Comité de No Intervención y la escasez de recursos del ejército republicano ante las fuerzas de Franco y sus aliados fascistas.

Para ilustrar estas líneas maestras, lejos de hacer un repaso por la producción cinematográfica realizada durante la contienda y la dictadura franquista, centraré mi estudio en tres películas que paradigmáticamente exponen el discurso legitimador que el franquismo estructuró desde sus orígenes hasta su desaparición, sin solución de continuidad. De esta forma, veremos como los mitos que comienzan a forjarse en España heroica (Joaquín Reig, 1937) apenas difieren de los que se representan veintiocho años después en Morir en España (Manuel Ozores, 1965). En todo caso, la segunda película presenta -si cabe- una mayor obsesión hacia lo que se consideró el peligro comunista. La razón es que tras el final de la Segunda Guerra Mundial el anticomunismo se erigió en la principal arma propagandística del franquismo en el exterior. Este mayor acento anticomunista quedó claramente reflejado, como veremos, en los cambios producidos en las dos versiones que se hicieron de Raza (Sáez de Heredia, 1941), la película autobiográfica del general Franco, que en 1950 pasó a titularse Espíritu de una raza.

Tampoco vamos a repasar las diversas producciones del bando republicano, entre las que se encuentran las realizadas por los sindicatos CNT-FAI y UGT o por la Generalitat de Cataluña, sino que nos centraremos en un film producido gracias al impulso del Gobierno de la República en su afán por ganar apoyos en el exterior: La obra de André Malraux, Sierra de Teruel, además del documental dramático de Joris Ivens, Tierra de España, el más alto ejemplo de producción cinematográfica internacional en favor de la República. Entremos, pues, en materia. 


\section{1}

Si más arriba hicimos referencia al momento que supone en el panorama actual la recuperación de la memoria histórica y el papel jugado por una película como Tierra y Libertad, fue precisamente el año del estreno de esta película -y coincidiendo con el sesenta aniversario del comienzo de la Guerra Civil- cuando el Partido Popular ganó las elecciones que le llevaron al Gobierno de España. A partir de entonces el pasado volvió a ser instrumentalizado políticamente y ante la inevitabilidad cada vez más manifiesta de mirar al mismo, comenzó una operación de revisionismo histórico que tuvo su punto más álgido coincidiendo con el Gobierno de mayoría absoluta de José María Aznar ${ }^{24}$.

Las tesis básicas (mitos en realidad) sobre los que se basa este revisionismo en nada difieren de las defendidas durante la dictadura franquista sin solución de continuidad, y que podemos observar en la producción fílmica del período ${ }^{25}$. Por otra parte, la versión cinematográfica de los acontecimientos del pasado no era sino correlato de una escritura de la historia oficial que estaba en manos de militares, policías, clérigos y publicistas, que dieron forma a las necesidades de legitimación de un régimen de dictadura, consciente de su ilegitimidad de origen $^{26}$. De esta forma, estos autores y cineastas no dudaron en falsificar la historia, presentando una imagen mitificada del régimen de dictadura, cuyos aspectos positivos se contraponían a otros negativos representados por el régimen constitucional de la II República ${ }^{27}$. Tres mitos destacan en este sentido, a saber:

1. Retrotraer los orígenes de la Guerra Civil nada más y nada menos que a los acontecimientos revolucionarios de octubre de 1934, hechos que demostraban la bolchevización del Partido Socialista a las órdenes de Moscú. Según esta lectura, Franco y los militares se habrían anticipado a los hechos, evitando la implantación del comunismo en España, que habría pasado a ser un satélite de la URSS.

2. El segundo mito insiste en la exageración del volumen de contingentes de ayuda internacional a la República, con especial atención a la influencia de la URSS, al tiempo que se reduce el peso que en la victoria final del ejército franquista tuvieron la ayuda fascista y nazi.

24. Ver Humlebaek, Carsten, «Usos políticos del pasado reciente durante los años de gobierno del PP», historiadelpresente.com, pp. 157-167 y AGUILAR, Paloma, "Guerra civil, franquismo y democracia", Claves de razón práctica, n. ${ }^{\circ} 140$, marzo de 2004, pp. 24-53.

25. Las claves de este revisionismo han sido claramente expuestas por RODRIGO, Javier, «Los mitos de la derecha historiográfica. Sobre la memoria de la guerra civil y el revisionismo a la española", historiadelpresente.com, pp. 185-195.

26. Una aproximación a la historiografía durante el franquismo en PRESTON, Paul, «La historiografía de la guerra civil española: de Franco a la democracia», en GRANJA J. L. de la, REIG TAPIA, A. y MiLLARES, R. Tuñón de Lara y la historiografía española, Siglo XXI, Madrid, 1999, pp. 161-174.

27. VIÑAS, Ángel, "Franco o la subversión de la memoria», en ARÓstEGUI, Julio (ed.), España en la memoria de tres generaciones, op. cit., pp. 100-119. Véase también, en el mismo volumen, la contribución de REIG TAPIA, Alberto, «La guerra civil, «lugar de memoria»», pp. 71-87. 
3. Por último, un tercer mito se refiere a la represión y violencia llevada a cabo en la zona republicana, abultando sus cifras a la vez que se relativiza o se silencia la desarrollada en la zona franquista ${ }^{28}$.

Veamos como estos mitos comenzaron a fraguarse en la misma Guerra Civil y se convirtieron en una constante en la auto-representación del régimen durante toda la dictadura. Para ilustrarlos utilizaremos en primer lugar un documental de montaje que supone un claro paradigma de la propaganda franquista: España heroica, dirigida en 1937 por Joaquín Reig, delegado de propaganda cinematográfica de FE y de las JONS en Alemania. La película fue producida por la Hispano Film Produktion, compañía berlinesa nacida con el principal objetivo de producir películas de propaganda favorables a la España rebelde, dentro de los acuerdos cinematográficos firmados entre el Gobierno de Burgos y el Tercer Reich $^{29}$.

Se trata del film propagandístico en favor de la causa franquista con mayor repercusión exterior, pues llegó a exhibirse ante una delegación del Comité de No Intervención, como "prueba» del desorden y el caos existente en la zona republicana. Esto fue posible gracias a que Joaquín Reig pudo montar la película con material rodado en las dos zonas, pues contó con algunas de las imágenes filmadas por Roman Karmen (sustraídas ilegalmente), además de las registradas por otros corresponsales extranjeros, que las distribuyeron libremente gracias a la escasa censura decretada por el Gobierno republicano ${ }^{30}$.

Sin duda, el contar con este importante material permitió completar un film que se erigiría como auténtico manifiesto de los sublevados, en el que se presentaban ordenadamente $-y$ con la presencia justificativa de las imágenes- los hechos que habían motivado la «necesidad histórica» del levantamiento militar. Todo ello quedaba articulado -en palabras de Carlos F. Heredero- «sobre la premisa de identificar al régimen republicano con el marxismo internacional y de convertir a sus gobernantes en cómplices de una conspiración comunista, para responsabilizar, a ambos, de todos los desmanes atribuidos al régimen constitucional» ${ }^{31}$.

28. Sobre la función de estos mitos durante la dictadura franquista ver REIG TAPIA, Alberto, «Los mitos políticos franquistas de la guerra civil y su función: el "espíritu» del 18 de julio de 1936», en Aróstegui, Julio y GodicheaU, François (eds.), Guerra civil. Mito y memoria, op. cit., pp. 201244.

29. Ver DíEz PUERTAS, Emeterio, «Los acuerdos cinematográficos entre el franquismo y el Tercer Reich (1936-1945)", Archivos de la Filmoteca, n. ${ }^{\circ} 33$, octubre de 1999, pp. 34-59.

30. El propio Reig declaraba que "con esto se demuestra que la verdad sobre la España roja de ningún modo se puede saber mejor que por los propios documentos cinematográficos de los rojos, en que ellos mismos nos muestran su caos y nos presentan su barbarie sin atenuantes de ningún género». Citado por Álvarez BerCiANO, Rosa y SAla Noguer, Ramón, El cine en la zona nacional, 1936-1939, Bilbao, Ediciones mensajero, 2000, pp. 238.

31. HeREDERO, Carlos F., La pesadilla roja del general Franco. El discurso anticomunista en el cine español de la dictadura, Festival Internacional de Cine de Donostia-San Sebastián, 2004, p. 50. 
Las palabras con las que comienza el documental dejan fuera de toda duda sus intenciones justificativas y una visión de los acontecimientos no exenta de toques racistas:

"De esta tierra, de estos cielos, de esta luz y de este aire ha salido una raza magnífica a la que hicieron perder la conciencia de su destino en lo universal (...) Pero llegó la hora de la prueba, y la alta España de Isabel y Fernando cae en manos de corrientes políticas incompatibles con su psicología étnica, y que favorecen más y más el funesto particularismo del pueblo español, y lo precipitan en un mundo en ruina moral, extinguido por toda suerte de diferencias». Poco después aparecen significativamente carteles de ESQUERRES CATALANES.

Tras esta exposición de "los orígenes», en pocos minutos (7-11) queda sintetizado en imágenes el principal argumento del film: Las escenas de la proclamación de la República son seguidas de disturbios callejeros y de formaciones de obreros y obreras que marchan disciplinadamente (curiosamente la única vez que aparecen disciplinados), dispuestos a iniciar la revolución. En ese momento, una imagen de la hoz y el martillo irrumpe cerniéndose amenazante sobre el mapa de España, a continuación de lo cual se da la noticia del asesinato de Calvo Sotelo, que "precipita la hora de la reacción». Seguidamente, tras el reparto de armas a un pueblo enfervorizado, se consuma la amenaza: «Rusia envía como embajador suyo a España a Moisés Rosenberg» ${ }^{32}$.

Debemos mostrar especial interés hacia la forma en la que se ha estructurado el discurso de esta secuencia por medio del montaje de las imágenes. De esta forma, la recepción de Rosenberg se combina con unos planos en los que la multitud ha profanado una serie de tumbas religiosas, dando a entender que el embajador soviético está siendo testigo privilegiado de unos hechos que, requerido por dicha multitud, no duda en aprobar asistiendo. Su llegada, por lo tanto, queda asociada a estos actos de barbarie.

La argumentación se completa con otra secuencia (minutos 11-15) en la que se muestra una pintada sobre una fachada que dice: «Formad el Partido Comunista. Os dará Pan, Paz y Trabajo», a continuación de la que se suceden imágenes del incendio de iglesias, la famosa escena del fusilamiento de la estatua de Cristo Rey por unos milicianos, el saqueo y quema de objetos de culto, un primer plano sobre cuerpos "de ciudadanos españoles rociados con benzina y quemados vivos", arrestos y ejecuciones. La secuencia se cierra con el plano de unos cadáveres abandonados sobre el asfalto.

32. El error en el nombre del embajador soviético, que de Marcel ha pasado a llamarse Moisés es interpretado por Sánchez-Biosca como un intento de asimilación entre judaísmo y comunismo, lo que concuerda con la influencia alemana sobre el film. Ver SÁNCHEZ-BIOSCA, Vicente, Cine y Guerra Civil Española. Del mito a la memoria, op. cit., p. 50. Como ha indicado Manuel Nicolás, el hecho de que desde este momento no haya referencia alguna a los líderes republicanos podía dar a entender que la República estaba siendo gobernada desde Moscú a través de Rosenberg. Ver NiCOLÁS MESEGUER, Manuel, La intervención velada. El apoyo cinematográfico alemán al bando franquista (1936-1939), Universidad de Murcia, 2004, p. 217. 
Es decir, la propaganda franquista comienza a explotar la exposición del caos y la barbarie existentes en la zona republicana (actos que justifican con carácter retroactivo la necesidad del levantamiento militar contra las «fuerzas republicano-marxistas»), junto a los vínculos de la República española con la URSS. Se trata de un discurso que Manuel Ozores llevó al paroxismo en su película Morir en España, en la que la «invasión soviética» pasó a ocupar el primer plano en la justificación del alzamiento. Así, destacan frases como: "El Frente Popular se forma a las órdenes de Moscú» o "la anarquía se extiende desde Madrid a toda la zona sovietizada». Y, tras mostrar escenas de ejecuciones llevadas a cabo durante la revolución rusa: "El comunismo ejerce su magisterio en España, todo se hace conforme a la enciclopedia revolucionaria rusa». El discurso, en suma, se ha estructurado para concluir que: "Rosenberg asiste a los consejos de gobierno donde dicta órdenes», a lo que añade: "Es la URSS quien gobierna».

Volviendo a España heroica, al último plano al que hacíamos referencia le sucede, por contraste, una nueva secuencia que comienza con el ondear de una bandera bicolor, al tiempo que se anuncia que "al frente de la reacción nacional surge el general Franco, aclamado como caudillo de la España nueva». Se completa así un discurso legitimador que ve en Franco al caudillo salvador de la patria, general en jefe de un ejército de liberación en continuo avance para reconquistar la «zona roja» y devolverla a la España «una, grande y libre».

Por lo tanto, el mito fundacional por excelencia, el del golpe preventivo, es esgrimido ya en estas primeras producciones, mito que persistirá a lo largo de toda la dictadura y que recientemente ha recobrado fuerza de la mano de una serie de publicistas a los que ha dado cobertura un historiador como Stanley Payne ${ }^{33}$.

El segundo mito al que hacía referencia es la sistemática devaluación de la ayuda política y militar dada a Franco por las potencias fascistas, mientras se insiste en la inflación de la ayuda soviética ${ }^{34}$. En este sentido, se procura mostrar el armamento soviético y se le da una enorme importancia a la presencia de las Brigadas Internacionales como constatación de la invasión comunista exterior. Es por esto que el éxito de la defensa de Madrid es atribuido únicamente a la llegada de las mismas, compuestas, según el film de Reig (las llama Columnas Internacionales), por una chusma que se dedica a emborracharse y despilfarrar a costa de un pueblo hambriento ${ }^{35}$.

33. PAYNE, Stanley, El colapso de la República. Los orígenes de la guerra civil (1933-1936), Madrid, La Esfera de los Libros, 2005.

34. Un estado de la cuestión sobre la verdadera significación de la influencia extranjera, en MORADIELLOS, Enrique, "La intervención extranjera en la guerra civil: un ejercicio de crítica historiográfica», Ayer, n. ${ }^{\circ} 50$ (2003), pp. 199-232.

35. Esta secuencia, incluida tras otra en la que la población hace largas colas para obtener «la escasa comida de que se puede disponer", comienza con el comentario: "Sin embargo, la columna internacional no carece de nada». En ella vemos diversos planos de milicianos comiendo, riendo y bebiendo con gestos ostensibles de embriaguez y holgazanería. Nada le importa al productor calificar como "columnas internacionales" a los que realmente son milicianos de la CNT-FAI, error 
El corolario a esta propaganda -pensando en la actitud del Comité de No Intervención- era ocultar en todo momento la ayuda recibida desde la Italia fascista y la Alemania nazi, tal cual hace el documental de Reig, y en lo que de nuevo insistiría Morir en España, evidentemente no negándola sino devaluándola (método recogido actualmente por Pío $\mathrm{Moa}^{36}$ ).

De esta forma, podemos oír en la película del director de Los bingueros, Yo hice a Roque III o Qué gozada de divorcio: "En el mundo, para tapar la intervención descarada de la no-intervención Franco-Soviética, se exagera la participación, todavía incipiente, de italianos y alemanes». En contraposición, y en apoyo de sus tesis, se debía mostrar continuamente el armamento soviético, como podemos leer en la sinopsis del guión presentado por José María Sánchez-Silva y Rafael García Serrano ante la Junta de Clasificación y Censura: "Tropas avanzando hacia Madrid, Marty, en su discurso y Hemingway con la toma de posesión de Rosenberg, mientras los tanques soviéticos y rusos actúan es España ${ }^{37}$. Como en España heroica, de nuevo se hacía una referencia al decisivo apoyo extranjero en la defensa de Madrid: "Todos los caminos españoles llevan a Madrid cuando comienza noviembre. Mientras en el ejército nacional no hay más que un puñado de aviones italianos alistados en la legión y unos cuantos técnicos alemanes, la Brigadas Internacionales llevan ya una buena temporada de entrenamiento en Albacete».

Sin embargo, el mito respecto a la inflación de la ayuda internacional a la República y la devaluación de la ayuda nazi e italiana al bando rebelde encontró su cenit en España heroica, al atribuir a incendiarios republicanos la destrucción que la Legión Cóndor hizo de Guernica. Sin duda, estamos ante el punto culminante del cinismo de la propaganda franquista, que era consciente de que suponía un problema de hondo calado para su posición. Esta visión era compartida por la propia Alemania nazi, interesada en que "se siguieran cumpliendo» los acuerdos de no intervención ${ }^{38}$.

En 1965, cuando nadie podía negar la destrucción de Guernica por la Legión Cóndor, cuando incluso se había traducido al español la obra la Southworth que demostraba la participación alemana con documentos originales, tanto en Morir en España, como en Franco ese hombre (Sáez de Heredia, 1964), sencillamente se ignora el acontecimiento cuando se habla de los avances del ejército franquista en la campaña del norte.

Pero ¿qué importancia le debemos dar hoy día a este silencio? ¿Qué importancia le debemos dar a lo que supuso el bombardeo de Guernica? Como

en el que volvería a incurrir Morir en España. Ver Crusells, Magí, La Guerra Civil española: cine y propaganda, Barcelona, Ariel, 2000, p. 125.

36. Ver la respuesta que a este autor hace ESPINOSA MAESTRE, Francisco, El fenómeno revisionista y los fantasmas de la derecha española, Badajoz, Los libros del oeste, 2005.

37. AGA, Cultura, Expediente de censura n. ${ }^{\circ} 35296$, caja 4145. Ambos guionistas volverían a colaborar un año después en la segunda respuesta cinematográfica al documental de Rossbif, ¿Por qué morir en Madrid? de Eduardo Manzanos, film que no llegó a exhibirse comercialmente. Ver CRUSELls, Magí, op. cit., p. 115.

38. NiCOLÁs MESEGUER, Manuel, La intervención velada. El apoyo cinematográfico alemán al bando franquista (1936-1939), op. cit., p. 264. 
Marcel Oms escribiera con motivo del 50 aniversario de la Guerra Civil, ¿Qué queda de Guernica comparado con Hiroshima? ${ }^{39}$ Evidentemente todo, Guernica sigue constituyendo un desgraciado hito en la historia de la barbarie, como se encargó de recordarnos Alain Resnais. En unos años en los que predominaba el olvido internacional de la Guerra Civil, «la opresión continúa», nos dice Resnais en un cortometraje realizado a principios de los cincuenta sobre la obra de Pablo Picasso, "Guernica».

No es casualidad que el realizador de La guerre est fine denunciara el olvido de la Guerra Civil. Alain Resnais ha dedicado la mayor parte de su filmografía a reflexionar sobre la memoria. Es quien primero reivindicó la necesidad de una memoria de los campos de exterminio, con su Nuit et Bruillard y fue el primero en denunciar el olvido de Hiroshima en su primer largometraje Hiroshima mon amour. Cuando rueda Guernica, obra poética de una intensidad extrema, Resnais acomete dos cuestiones. La primera, reivindicar la destrucción de la población de Guernica -a la que califica como crimen contra la humanidad ${ }^{40}$ - como uno de los momentos clave de la historia de la violencia y la barbarie del siglo XX. En este sentido, la obra de Picasso supone una expresión absoluta del horror, del dolor, del sufrimiento. Gritos desgarrados de incomprensión ante el primer bombardeo sistemático sobre una población civil, cuando «la muerte interrumpió el bienestar del tiempo ${ }^{41}$. Esto es la guerra más allá de la propaganda, pura expresión del horror:

«Sangre en los hombres, sangre en las bestias. Una cosecha tan repugnante y asquerosa que incluso los carniceros parecen puros y limpios. Intenta controlar a la bestia sintiendo la muerte inminente. Intenta decirle a una madre por qué murió su hijo. Intenta alcanzar consuelo en tanta destrucción. Los restos de la noche de la guerra, hermana de la miseria e hija de la muerte, repugnante, espantosa» ${ }^{42}$.

La segunda cuestión es paradójica, ya que manifiesta la oportunidad del arte como forma de una memoria que perdura más allá de la barbarie. La inocencia -nos viene a decir-, permanece en el arte como oposición al crimen. El cine, pues, no como propaganda, sino como depósito de memoria, donde el horror

39. OMS, Marcel, «La guerra civil española vista por el cine», en Dirigido por ..., n. ${ }^{\circ}$ pp. 10-15.

40. El delito de "crimen contra la humanidad" fue tipificado en el acuerdo de Londres del 8 de agosto de 1945, por el que se creaba el Tribunal Penal Internacional de Nuremberg para juzgar los crímenes cometidos en Europa por la Alemania nazi. Este delito se refiere a «el asesinato, el exterminio, la esclavización, la deportación y cualquier otro acto inhumano cometido contra todas las poblaciones civiles antes o durante la guerra, o bien las persecuciones por motivos políticos, raciales o religiosos». Hubo que esperar tres años y cuatro meses para que, el 9 de diciembre de 1948, una Convención de la ONU tipificara una nueva figura jurídica: la de genocidio. La principal diferencia con la de "crimen contra la humanidad» es que el genocidio tiende a la destrucción total o parcial de un grupo humano definido de antemano. Ver BRUNETEAU, Bernard, El siglo de los genocidios..., op. cit., p. 16.

41. Del guión de Paul Elvard, con narración de María Casares.

42. El dramatismo de la narración se intensifica al realizarse junto a la sucesión de diversos planos sobre los innumerables bocetos que Picasso realizara para su obra, y que gracias a la música de Guy Bernard alcanza una intensidad extrema. 
queda superado únicamente por un arte que persevera en la denuncia. Pero es paradójico porque, al mismo tiempo que realiza este canto al arte como superación de la barbarie, Guernica no hace más que confirmar -como apuntara Román Gubern- que en la Europa de los cincuenta «la tragedia de la Guerra Civil era algo inactual que ya sólo tenía cabida en los museos» ${ }^{43}$. Eran los años del boom económico europeo, la historia seguía su curso, olvidando la experiencia fascista. Mientras «la tierra gira en su órbita, vosotros pudriéndoos solos», concluye Resnais.

El tercer y último mito en la auto-representación del franquismo al que hicimos referencia es el de la represión llevada a cabo en ambos bandos. Morir en España se centra en uno de los lugares míticos de la violencia republicana, visitando el cementerio de Paracuellos del Jarama, donde "caerán asesinados más de 11.000 patriotas en dos días». A lo que, tras calificar el asesinato de Federico García Lorca como triste episodio propio de unos días de confusión, añade: «Por ambos bandos se cometieron excesos en aquel sangriento verano, sin embargo en la zona nacional fueron ruda y rápidamente frenados por la estricta justicia militar» y concluye: "Los muertos de la zona nacional son de tercera porque son muertos sin propaganda". Nada se menciona, por supuesto, acerca de la represión de posguerra.

En cuanto a España heroica, la película concluye con el mito de la muerte de los mártires, encabezados por el «ausente» José Antonio Primo de Rivera. De clara inspiración fascista y con cierta influencia de El triunfo de la voluntad (Trumph des Willens, 1934) de Leni Riefenstahl, asistimos a unos planos en los que se instaura ese "culto a los caídos" de un solo bando, que llenará de cruces y nombres todos los pueblos de la geografía española. A partir de este momento, cruces públicas y fachadas de iglesias recordarán a «las víctimas del terror rojo y del ateísmo soviético, inmoladas bárbaramente por pelotones de asesinos y asalariados de Moscú», tal y como, recogiendo noticiarios de la época, nos recuerda irónicamente la demoledora película de Basilio Martín Patino, Canciones para después de una guerra. La película levantó ampollas incluso antes de su estreno, preguntándose Carrero Blanco, quién mandara prohibir y secuestrar la película terminada en 1971, "cómo es que no están ya fusilados los que la han hecho»". Casi en un mismo sentido amenazante se expresaba Carlos F. de Avellanos en las páginas de El Alcázar, desde donde arremetía contra la película no estrenada:

«Realmente hay momentos de la locución que dan ganas de decir jmuérase ya amigo!» Añadiendo: «Cada uno es muy libre de decir lo que quiera y como quiera, siempre que diga la verdad. Pero dejar que cuente una época tan decisiva de la historia actual de un país un llorón de este calibre y que lo haga, además, tan parcialmente, se nos antoja, cuando menos una estupidez. Y las estupideces cuestan caras» ${ }^{45}$.

43. GUBERN, Román, 1936-1939: La guerra de España en la pantalla, op. cit., p. 117.

44. En declaraciones del coguionista GARCíA SÁNCHEZ, José Luis, "Materiales para canciones para después de una guerra», en YraOla, Aitor (comp.), Historia Contemporánea de España y Cine, Madrid, UAM Ediciones, 1997, pp. 107-114, p. 108.

45. Carlos F. de Avellanos era el seudónimo de Félix de Martialay. Citado por SÁnCHEZ-BiosCA, Vicente, Cine y guerra civil española, op. cit., p. 254. El artículo llevaba por título "Canciones para después de una guerra o llanto para después de una paz», El Alcázar, 4 de junio de 1971. 
Los mitos forjados durante el conflicto bélico fueron heredados y potenciados en la posguerra por el "cine de cruzada», tal cual lo denominó Román Gubern, fundamentalmente en lo que hace referencia a la exaltación de la figura providencial de Franco como "Caudillo» salvador de España.

La película paradigmática en este sentido es Raza, realizada por José Luis Sáez de Heredia a partir de un guión escrito por el propio dictador bajo el seudónimo de Jaime de Andrade, con claros tintes autobiográficos ${ }^{46}$. Por ello, su argumento refleja de forma recurrente la mentalidad (esquizoide en palabras de Gubern) desde la que fue concebida: A la decadencia histórica en la que se había visto sumida España, le sigue el resurgimiento bajo la espada invencible de un Caudillo que, tocado por la providencia, ha evitado que terminase cayendo en las garras del comunismo.

Hay una escena que resume este sentido: José Churruca (papel que representa al propio Franco) es tomado prisionero y fusilado por un pelotón de milicianos. Tras la descarga, el protagonista cae al suelo herido de muerte (aunque la providencia se encargará de que sobreviva milagrosamente), momento en el que la cámara -en el mismo plano- concentra su enfoque sobre la pared del fondo para que leamos la pintada que hasta ese momento permanecía oculta tras la figura del héroe ejecutado: ¡Viva Rusia! ${ }^{47}$. Este discurso de exaltación patriótica se completa con la adjudicación al bando republicano (la anti-España) de todo tipo de atrocidades contra la religión y el orden.

Sin embargo, he traído a colación esta película para reseñar la naturaleza de los cambios efectuados en una segunda versión del film que, realizada en 1950, se estrenará con el nuevo título de Espíritu de una raza, retirándose de circulación la versión de 1941. El objetivo no era otro que lavar definitivamente la imagen del régimen en cuanto a su pasado fascistizado y amoldarlo a su posición geoestratégica en la guerra fría, cuando el bloqueo exterior estaba cerca de finalizar. Por esta razón, la imagen del enemigo comunista se potenciará en este período, pasando el anticomunismo a convertirse en la pieza clave que justificaba el

46. Sobre las características autobiográficas y psicoanalíticas de la película ver el imprescindible ensayo de GUBERN, Román, Raza, un ensueño del general Franco, Madrid, Ediciones 99, 1977. Ver también ElORZA, Antonio, "Mitos y simbología de una dictadura", Bulletin d'Historia Contemporaine de l'Espagne, n. ${ }^{\circ} 24$, décembre 1998, pp. 47-68.

47. Es curioso como en Franco ese Hombre (1964), de nuevo Sáez de Heredia insiste en el carácter sobrenatural con el que el Caudillo venció a la muerte. El director entrevista al doctor Blasco Salas, que atendió a un joven Franco tras ser herido en el vientre en la batalla de Biutz: "SH: ¿Cuál fue su diagnóstico antes de reconocerle? BS: Muerto. SH: ¿Puede usted decirnos en qué consistió esa herida calificada por usted y por otros médicos como milagrosa? BS: (Indicando en la radiografía) la bala entró por el vientre y siguió al hígado, pero estaba Franco en inspiración forzada, o sea, que el diafragma se levantaba hacia arriba y la bala rozó el diafragma por abajo y salió por detrás. Pero claro, si Franco tiene una inspiración natural, una respiración, no inspiración, pues la bala hubiera atravesado el hígado y se hubiera muerto». Y, volviendo a imágenes de la campaña de África, concluye el narrador: "La muerte estaba alli para todos. También para Franco, pero este sonriente capitán, tan repetidamente ofrecido a las balas, parecía tener, en efecto, lo que los moros que mandaba llamaban en su lengua baraka: tener baraka es para ellos tener la protección de las fuerzas prodigiosas". 
papel de España y su Caudillo en Occidente ${ }^{48}$. De esta forma, el cine ponía de manifiesto una constante del régimen de Franco, la capacidad de adaptación e inmovilismo en su afán por permanecer en las distintas coyunturas con la que hubo de coexistir ${ }^{49}$.

Los cambios producidos en ambas versiones comienzan a constatarse en el letrero inicial que aparece tras los títulos de crédito (ausente en la versión original). Supone una auténtica declaración de intenciones, al exponer que la historia que se narra: "Es historia pura, veraz y casi universal que puede vivir cualquier pueblo que no se resigne a perecer en las catástrofes que el comunismo provoca».

Los diálogos también se actualizaron en clave única y exclusivamente anticomunista. Así, cuando el general comunista se dirige a Pedro Churruca (el Ramón Franco de la película) tras descubrir su traición, le dice: "Yo nunca me he tragado que tú fueras un verdadero comunista», donde en la primera versión se decía: «un verdadero antifascista». $O$ en la arenga final de éste antes de ser fusilado, cuando en referencia a los combatientes franquistas, proclama: "ganarán siempre la batalla contra el comunismo bárbaro y ateo", donde en la primera versión se decía: "contra los hombres huecos» ${ }^{50}$.

Por último, además de suprimirse las alusiones críticas a la masonería -otro de los demonios del régimen-y a los Estados Unidos en la Guerra de Cuba, fueron eliminadas todas las escenas que pudieran recordar al fascismo, como los saludos a la romana, el plano del retrato de José Antonio, la secuencia de la jota en honor de la Falange y la melodía del Cara al Sol, que aparecía en los títulos de crédito de la primera versión ${ }^{51}$.

\section{3}

En cuanto a la producción en el bando republicano, nos centraremos en el comentario de dos películas nacidas con idénticos propósitos de movilizar a la opinión pública internacional en favor de una democracia agredida por el fascismo ${ }^{52}$. La primera es la película de André Malraux Sierra de Teruel (Espoir, 193839) y que nos sirve para rebatir las tesis actuales revisionistas sobre la inflación de la importancia de la ayuda exterior a la República, ya que el motivo principal de la misma fue precisamente convencer al Comité de No Intervención de la

48. Un seguimiento de la evolución del discurso anticomunista a lo largo de toda la dictadura en HEREDERO, Carlos F., La pesadilla roja del general Franco..., op. cit.

49. Ver SÁNCHEZ RECIO, Glicerio, "Inmovilismo y adaptación política del régimen franquista», en Moreno Fonseret, Roque y SeVillano Calero, Francisco, El franquismo. Visiones y balances, Alicante, Universidad de Alicante, 1999, pp. 27-43.

50. HeREDERO, Carlos F., La pesadilla roja del general Franco..., op. cit., p. 57.

51. Ver el estudio comparado de ambas versiones, en CAPARROS LERA, José María, Estudios sobre el cine español del franquismo (1941-1964), Valladolid, Nancy Ediciones, 2000, pp. 15-31.

52. Ambas películas son presentadas como una lucha genérica contra el fascismo y en ambas, que tenían como principal destinatario el mercado norteamericano, se evita hablar de comunistas o anarquistas, amén del conflicto religioso. Todo lo contrario a una película contemporánea que tenía como destinatario al pueblo ruso: Ispanija (Esther Shub, 1939), en la que el mayor peso de la lucha antifascista es atribuido a los comunistas. 
necesidad de cambiar su política, por lo que hay continuas referencias a la baja calidad, cuando no carencia, del armamento del bando republicano. La segunda es Tierra de España (Spanish Earth, 1937), la película realizada por el prestigioso documentalista holandés Joris Ivens y que, más allá de lo que significó en su momento, convendría interpretarla a la luz de la historiografía actual, teniendo en cuenta el concepto de Guerra total, dada la intención de la película en presentar el esfuerzo de un pueblo en solidaridad con el frente, ante la opresión de un ejército levantado en armas contra la libertad del mismo ${ }^{53}$.

Antes de entrar en el comentario de ambas películas, hay que decir que el material audiovisual generado durante la Guerra Civil es inseparable de la aportación de los realizadores extranjeros, más de cien operadores y seiscientos colaboradores que trabajaron cerca del frente entre 1936 y 1938. Entre ellos cabe destacar, además de la aportación de los dos autores citados, a otros como Ivor Montagu o Roman Karmen, quien rodó en casi todos los frentes decisivos entre 1936 y 1937, de tal forma que el legado que nos dejó supone el capital fílmico más importante sobre la Guerra Civil española. Prácticamente todos los filmes de montaje realizados durante y después de la contienda, han utilizado las imágenes rodadas por el realizador soviético.

Sierra de Teruel fue un proyecto de André Malraux que pronto se convirtió en la principal apuesta de la política cinematográfica del Gobierno de la II República, que la produjo con 750.000 pesetas y 100.000 francos de la época. Tras su experiencia como combatiente de la Escuadrilla España (organizada y dirigida por él mismo), el autor de L'Espoir se dedicó a recabar ayuda a favor de la España republicana, pronunciando conferencias en distintas universidades norteamericanas como miembro de la Alianza de Intelectuales Antifascistas. Fue en uno de esos viajes cuando tomó forma el proyecto de realizar una película de propaganda que sirviera para sensibilizar a la opinión pública internacional en favor de la causa republicana. Por ello, y tras el relativo alcance que en este mismo sentido había tenido el documental de Joris Ivens, optó por realizar una película de ficción que fuera capaz de llegar al gran público, trasladando la imagen de una República democrática asediada por el fascismo internacional y abandonada a su suerte por las democracias occidentales. Esta labor venía facilitada, además, por el ofrecimiento que una organización liberal estadounidense le había hecho a Malraux: La oportunidad de contar con un circuito de 1.800 salas para su proyección, con una audiencia estimada de 2.000 espectadores diarios ${ }^{54}$.

El propósito no era otro que movilizar a la opinión pública estadounidense contra el embargo de armas con destino a España, votado por el Congreso

53. Con la "Guerra total», la Guerra Civil adquiere definitivamente su significado profundo de "guerra a los civiles", ver RANZATO, Gabriele, "Guerra totale e guerra civile nel XX secolo", Parolechiave, n. ${ }^{\circ} 20-21$ (1999), pp. 239-258; Ver, en este mismo sentido, las contribuciones al concepto de guerra civil de BOBBIO, Noberto, "Guerra civile?», Teoria politica, VIII, n. ${ }^{\circ} 1-2$ (1992), pp. 297-307 y GONZÁLEZ CALLEJA, Eduardo, «Reflexiones sobre el concepto de guerra civil», Gladius, 2000.

54. GUBERN, Román, 1936-1939: La guerra de España en la pantalla, op. cit., p. 32. 
americano el 6 de enero de 1937. Sin embargo, el avance de los frentes fue dificultando la producción hasta el extremo de tener que ser acabada en Francia. De esta forma, la función que en principio se le había dado a la película resultaría inoperante, ya que no estuvo montada y lista para ser proyectada hasta junio de 1939 , tarde ya para la causa republicana ${ }^{55}$.

Como escribiera Román Gubern, estos factores históricos y políticos determinaron la producción de Sierra de Teruel y quedaron especificados en los dos ejes centrales de la película: mostrar la penuria material y militar del bando republicano e invocar la solidaridad internacional en la lucha contra el fascismo ${ }^{56}$. Debemos destacar algunas secuencias en este doble sentido.

En cuanto al primer punto destacan tres momentos: La recolección de recipientes domésticos para fabricar bombas improvisadas, las quejas por la escasez de aviones de combate y de armas en las que se hace una clara referencia a la no-intervención cuando se muestran unos aparatos faltos de motores, y la búsqueda de automóviles para poder iluminar con sus faros la operación de despegue nocturno en un pequeño campo de aviación republicano.

En cuanto al segundo punto, la lucha en inferioridad contra el fascismo termina convirtiendo la película en un canto épico a la solidaridad, ya que la acción de los voluntarios extranjeros que componen la escuadrilla aérea se funde con el reconocimiento y apoyo que le dan los campesinos en la memorable secuencia final. En ella, tras el accidente aéreo sufrido por uno de los aviones republicanos, consecuencia de los daños sufridos tras el ataque a un campo de aviación franquista, los campesinos y campesinas de los pueblos cercanos colaboran en el descenso de las víctimas desde lo alto de la montaña, formando esa "Pietà laica para el hombre del siglo XX", como la calificara James Agge en su momento ${ }^{57}$. Por ello, como ha escrito Santos Zunzunegui, esa escena final del homenaje popular a los combatientes se convierte -en abierta contradicción con el título de la novela sobre la que está basada la película- en una lápida funeraria, la de la República española ${ }^{58}$.

En definitiva, el film de Malraux es algo más que una película de propaganda impulsada por la voluntad de un Gobierno legítimo. Estamos ante una obra de arte, ante el testimonio de un intelectual cuyo compromiso político le llevó a combatir por la libertad en unos años en los que el fascismo desafiaba a Europa. Y lo hizo desde todos los frentes desde los que le fue posible, incluido el de la cultura. Es su experiencia como piloto en el frente y como intelectual comprometido en la retaguardia lo que nos llega ahora, desde la ficción literaria y cinematográfica, como forma de memoria del testigo.

Otro ejemplo de memoria del testigo es el documental dramático de Joris Ivens Tierra de España. Fue el propio cineasta quien declarara pasados los años

55. Véase el excelente estudio de ZunZuneGui, Santos, Historias de España. De qué hablamos cuando hablamos de cine español, Valencia, Ediciones de la Filmoteca, 2002, pp. 27-44.

56. GUBERN, Román, 1936-1939: La guerra de España en la pantalla, op. cit., p. 32.

57. Citado por ZUNZUNEGUI, Santos, op. cit., p. 41.

58. Ibidem, p. 44. 
que «El film ha tenido una triple acción: una acción directa, política e ideológica, una acción inmediata y material para la compra de ambulancias y una acción histórica de testimonio para el futuro ${ }^{59}$.

Como el film de Malraux, su objetivo principal era movilizar a la opinión pública estadounidense, además de recaudar fondos para la República. Los dos ejes en torno a los cuales se organizó la película fueron la defensa de Madrid y la acción de un pueblo que, en la retaguardia, contribuía a su defensa cultivando los alimentos para abastecer la capital ${ }^{60}$. Este aspecto, junto al hecho de que Ivens, con la ayuda de Hemingway, decidiera rodar la guerra desde dentro, desde sus aspectos más crueles y destructivos, son los que nos permiten enfocar la película desde la actualidad a partir del concepto de Guerra total, esa guerra caracterizada no sólo por la movilización de todos los recursos, humanos y económicos, hacia la necesidad de los frentes, sino por la brutal indistinción que se produce entre frentes de batalla y retaguardia, entre militares y civiles como víctimas de la misma ${ }^{61}$.

Para ello, y en paralelo a la pregunta que se hiciera en su momento Marcel Oms sobre la actualidad de Guernica -y que hemos respondido con la obra de Resnais-, formularé otra pregunta que trataré de responder con la obra de dos cineastas muy significativos desde el punto de vista de la utilización del cine como forma de pensamiento. ¿Qué significación pueden tener hoy día aquellas imágenes de los bombardeos sobre Madrid, de aquellos niños y niñas muertos sobre el asfalto o enterrados bajo los escombros, como también podemos ver en España 1936 y que tanto impactaron al propio presidente Roosevelt, ante quien se realizó la primera proyección del documental de Ivens?

Para responderla quiero hacer una reflexión en torno a la cultura de la imagen, del absoluto dominio de la imagen en la que hoy vivimos. Pierre Sorlin, al referirse al papel de los medios de comunicación audiovisual en las guerras, divide el siglo XX en dos claras mitades: la sociedad pre-televisiva y la sociedad pos-televisiva. Atendiendo a esta división debemos distinguir -con Régis Debray- entre lo visual y efímero, donde la imagen ha intentado suplantar lo real, convirtiéndose en referente únicamente de sí misma (propio de la imagen tele-

59. Citado por GUBERN, Román, 1936-1939: La guerra de España en la pantalla.., op. cit., p. 46.

60. SAla NOGUer, Ramón, El cine en la España republicana durante la guerra civil, Bilbao, Mensajero, 1993, p. 385.

61. La implicación de los civiles como víctimas de la violencia depende de dos factores: La ideologización de la misma, mediante la definición y deshumanización del enemigo, que pasa a ser objetivo de la violencia aplicada en retaguardia, con fines de depuración; y el grado de modernización tecnológica, dos elementos que han ido de la mano como una de las particularidades que han definido la naturaleza de la violencia de guerra en el siglo XX. Fue durante la Guerra Civil española cuando se aplicaron por primera vez de forma sistemática los bombardeos aéreos contra la población civil. La guerra desde el aire, ejemplo de fusión entre violencia y desarrollo tecnológico, tuvo un devastador impacto material y, sobre todo, psicológico, en tanto en cuanto demostraba una extraordinaria capacidad para golpear todas las esferas de la vida social, colectiva y privada de los territorios enemigos. Ver DE GIOVANNI, Marco, "Violenza e tecnica. Fenomenologia bellica e coscienza collettiva nel novecento", Parolechiave, n. ${ }^{\circ} 20-21$ (1999), pp. 211-237. 
visiva), y la imagen significante, una imagen que nos interpela como referente de lo real y que actúa como depósito de memoria ${ }^{62}$. Hoy vivimos ante el predominio aplastante de la televisión, una televisión que ha convertido la guerra en un espectáculo que ya no es referente de lo real, sino que trata precisamente de suplantarlo, provocando la absoluta banalización y consecuente indiferencia.

Lo grave del predominio actual de las imágenes es precisamente que suponen una irrupción continua de violencia, a la que acabamos acostumbrándonos cotidianamente desde la pantalla de nuestros televisores. Pero la muerte nada tiene que ver con lo que se ve en la televisión. Como se nos muestra en el documental de Ivens, y como nos recuerda alguien que vivió la guerra de niño como Emilio Lledó, la muerte conmociona, las explosiones rompen los tímpanos y el humo y la sangre huelen ${ }^{63}$.

Sin embargo, los medios de comunicación son hoy tan perfectos que fingen la realidad y terminan por confundirla, mostrándola así más aceptable. Son problemas que nos tocan muy de cerca y sobre los que nos advierten dos grandes cineastas, muy preocupados por el significado ético de las imágenes cinematográficas, como son Theo Angelopoulos y Jean-Luc Godard ${ }^{64}$. Los dos, precisamente, a partir de la reflexión sobre una guerra civil a la que miran como reflejo de todas las guerras civiles del siglo XX, la de los Balcanes ${ }^{65}$.

62. SORLIN, Pierre, "Guerra, medios audiovisuales y sociedad», Film-Historia, vol. III, n. 1-2 (1993), pp. 7-18. DeBraY, Régis, Vida y muerte de la imagen. Historia de la mirada en Occidente, Barcelona, Paidós, 1994; Parece claro que el principal referente a lo visual y efímero sería la primera Guerra del Golfo, televisada en directo como si de un videojuego se tratase, mientras que otra guerra también cubierta por los medios audiovisuales, como fue la de Vietnam, nos ha legado unas imágenes (recuérdese la famosa fotografía de la niña que horrorizada deambula por una carretera tras un ataque de las fuerzas estadounidenses con napalm) que hoy constituyen parte de la memoria de aquel horror. Ver FECÉ, Josep Lluís, «La cámara cinematográfica ante la realidad», Cinema, art i pensament, d'humanitats, n. ${ }^{\circ} 6$ (1999), pp. 31-42.

63. El propio Ivens reconstruyó los sonidos de los bombardeos (la película había sido rodada en versión muda), atendiendo a sus impresiones subjetivas y a las de Hemingway, como testigos de los mismos. Como ha escrito Ramón Sala, se trababa de obtener «no un sonido que reproduzca lo más verosímilmente un bombardeo o los ruidos de un combate, sino las sensaciones que ese combate o bombardeo producen en un individuo inmerso en una ciudad que está siendo destruida", en SALA NOGUER, Ramón, El cine en la España republicana durante la guerra civil, op. cit., p. 395. Los comentarios de Emilio Lledó en la entrevista que le dedica el especial de El País, una historia de 30 años, jueves, 4 de mayo de 2006, pp. 402-408.

64. Debemos destacar las reflexiones que, en un mismo sentido, realizara Dzevad Karahasan respecto a un tipo de literatura que, tras despojar el componente ético del arte en beneficio de lo puramente estético, ha dejado de "proteger» a la gente de la indiferencia que les deshumaniza: «La gente que observa las escenas más terribles de dolor de sus semejantes y las vive sólo como una emoción estética, la gente que convierte la muerte en estética y acepta mirar los peores tormentos para, al menos, sentir algo por un instante (...) son personas esclavas de la estética del arte moderno indiferente», en Sarajevo. Diario de un éxodo, Barcelona, Galaxia Gutenberg, 2005, p. 101. Sobre la necesidad del compromiso moral en la novela y el arte, ver también la obra de KunderA, Milan, El arte de la novela, Barcelona, Tusquets, 1996.

65. Sobre la naturaleza de las guerras civiles en la Europa de los siglos XIX y XX puede consultarse el libro de RANZATO, Gabriele, Guerre fratricida. Le guerre civile in età contemporanea, Torino, Bollati Boringhieri, 1994. Ver también WALDMAN, Peter y ReInARES, Fernando (comps.), Sociedades en 
Conduciéndonos a la ciudad de Sarajevo, Godard, en la primera parte de Notre musique, hace -en palabras de Carlos Losilla- "cine renunciando al cine», porque las imágenes que lo formaron ya no significan. Precisamente, Godard defendía la "obligación» que tiene el cineasta de hacer en todo momento un homenaje a la imagen y el sonido anteriores a él. Sin embargo, en esta ocasión constata que ya no puede, porque esas imágenes han sido desplazadas por las continuas imágenes del horror ante las que ningún cineasta puede hacer nada: "las imágenes de una guerra sin fin» que jalonan el siglo XX ${ }^{66}$.

Es similar a lo planteado por Angelopoulos en La mirada de Ulises, cuando, en la secuencia final de Sarajevo, nos hace ser "testigos» del asesinato de una familia sin que lo podamos ver, impedidos por un espeso banco de niebla que ha cubierto toda la imagen. Precisamente, el vaciado de la pantalla hace que sea el sonido de los disparos lo único que nos permite acceder a lo que está pasando, intuyendo de forma más abstracta y, por lo tanto, más conceptual, la emergencia del dolor y de la muerte ${ }^{67}$. Estamos ante la representación puramente fílmica de la incapacidad a la que ha llegado el cine para reflejar la barbarie y la muerte; ante una mirada que sólo es capaz de registrar -en palabras del protagonista- «huellas vacías del mundo».

La propia importancia de la imagen vacía, la incapacidad de esa mirada cegada precisamente por saturación y que el cineasta trata de recuperar durante toda la película, es esencial en la denuncia planteada por Angelopoulos y es clave para volver a mirar, a setenta años de distancia, la barbarie que supusieron los bombardeos aéreos de la Guerra Civil española y que Ivens, como Roman Karmen, registraron de primera mano ${ }^{68}$.

guerra civil. Conflictos violentos de Europa y América Latina, Barcelona, Paidós, 1999 y CASANOVA, Julián (comp.), Guerras civiles en el siglo XX, Madrid, Pablo Iglesias, 2001.

66. Ver, en este sentido, los comentarios de Losilla, Carlos, en Dirigido por.., n. ${ }^{\circ} 358$, julio-agosto 2006, pp. $72-73$.

67. Ver el excelente trabajo de HEREDERO, Carlos F., «La mirada de Ulises», Nosferatu. Revista de cine, n. ${ }^{\circ} 24$, mayo de 1997, pp. 98-110.

68. Como reflexiona Pierre Sorlin, mientras hoy los conflictos desde Occidente se conocen sólo a través de los medios de comunicación, en 1939 no se distinguía entre lo que se veía en la pantalla y la realidad. El problema es que en nuestro tiempo, en palabras del autor citado, «si el concepto de conflicto es bastante claro para todos, la noción de guerra como principio de destrucción de nuestras casas y como principio de muerte se ha borrado. La guerra es, antes que nada, un espectáculo». Reflexiones análogas están en la base de la denuncia que hace Angelopoulos en La mirada de Ulises, esa pérdida que el cine-invadido y desbordado por la televisión- ha sufrido en su capacidad de mirar y mostrar la realidad para transmitir el conocimiento, especialmente cuando se trata del conocimiento de una realidad tan hiriente como la guerra. En este sentido, debemos recordar que el significado etimológico de la palabra mirada (sobre la que gira toda la película, desde el propio título hasta su última imagen) es theoria (lo que se ve), ya que la mirada era considerada un principio de conocimiento en el mundo griego, un camino hacia el descubrimiento y desarrollo del Logos. Ver los ensayos de Emilio Lledó sobre el mundo homérico y la filosofía de la Grecia Clásica en LLEDÓ, Emilio, Elogio de la infelicidad, Valladolid, Cuatro Ediciones, 2005 y Memoria del Logos, Madrid, Taurus, 1996; El surco de tiempo, Barcelona, Crítica, 1992; Imágenes y palabras, Madrid, Taurus, 1998. Es el propio Angelopoulos quien ha señalado la influencia de la tradición clásica en su obra, pues dejaba fuera del escenario toda representación 


\section{EN BUSCA DE LA MEMORIA PERDIDA. DEL "NUEVO CINE ESPAÑOL» A LA DEMOCRACIA}

El segundo momento que hemos seleccionado como formación de una memoria de la Guerra Civil en el cine es el que podemos ver en las producciones realizadas por esa segunda generación, la de los «hijos de la guerra». Es un período que se extiende desde la década de los años sesenta hasta la de los ochenta, y cuyo inicio debemos enmarcar dentro del cambio social y cultural que se produce en España, consecuencia del desarrollo económico, la influencia del turismo, la formación de una clase media y cierta relajación en la censura ${ }^{69}$.

En lo que al contexto cinematográfico se refiere, el punto de inflexión, tras los primeros pasos dados en las conversaciones cinematográficas de Salamanca, es el retorno a la Dirección General de Cinematografía y Teatro, y de la mano del gabinete "aperturista» de Manuel Fraga, de José María García Escudero, participante en dichas conversaciones. Efectivamente, desde mediados de los años cincuenta algo, aunque tímidamente, se estaba moviendo. Las protestas estudiantiles que inmortalizó Juan Antonio Bardem en Muerte de un ciclista son prueba de ello. Se trataba, de todas formas, de movimientos en la elite de una sociedad que comenzaba a hacerse preguntas sobre sí misma, una sociedad que, en palabras de Manuel Vázquez Montalbán, pese al poder omnipresente del franquismo, "trataba de encontrar su propia música» ${ }^{70}$.

En este contexto, el impulso dado por García Escudero abogaba por producir un cine de calidad que fuera capaz de competir en los festivales internacionales, razón por la que pudieron nacer películas como Nueve cartas a Berta (Basilio Martín Patino, 1966) o La Caza (Carlos Saura, 1966), que serían premiadas en los mismos ${ }^{71}$.

Sin embargo, la incompatibilidad entre la necesidad de ofrecer una imagen modernizadora de España -en unos momentos en los que el turismo se había convertido en la primera fuente de divisas-, y el inmovilismo inherente al mantenimiento sin fisuras de un poder autoritario, hará que el régimen entre en una enorme contradicción. Además, este nuevo contexto venía marcado por la influencia de la doctrina de reconciliación nacional y la celebración de los XXV años de paz, necesaria tras la manifestación que en este sentido había hecho el PC en 1954 desde el exilio.

de la muerte y la violencia, que eran descritas por medio de la palabra. Ver HoRTON, Andrew, El cine de Theo Angelopoulos. Imagen y contemplación, Madrid, Akal, 2001, p. 173.

69. Para una aproximación general ver GUBERN, Román, La censura. Función política y ordenamiento jurídico bajo el franquismo (1936-1975), Barcelona, Península, 1981.

70. En el prólogo al libro de Heredero, Carlos F., La pesadilla roja del general Franco, op. cit., pp. 11-16.

71. ARAGÜEZ Rubio, Carlos, «La política cinematográfica española en los años sesenta: la propaganda del régimen a través del nuevo cine español (1962-1967)", Sociedad y Utopía. Revista de Ciencias Sociales, n. ${ }^{\circ}$ 27, mayo de 2006, pp. 77-92. Agradezco al autor el haberme facilitado la documentación de archivo y hemerográfica citada para Morir en España, Canciones para después de una guerra y La prima angélica. 
Estas contradicciones tuvieron su plasmación más sangrienta en la ejecución de Julián Grimau, miembro del Comité Central del PCE, y la de los anarquistas Francisco Granados Gata y Joaquín Delgado Martínez en 1963, un año antes de la celebración de los pomposos XXV años de paz.

Son contradicciones que quedaron también reflejadas en la producción cinematográfica sobre la Guerra Civil, ya que al tiempo que se toleraban películas como La Caza, con la que se proyectaba una imagen más "aperturista» del régimen en el exterior, se seguían realizando otras como Franco ese hombre, en la que el realizador de Raza, Saéz de Heredia, volvía a servir a Franco en una película hagiográfica. Se trata de un auténtico culto a la personalidad de un "Caudillo» que, como héroe providencial, había salvado a España - «la reserva espiritual de Occidente»- de las garras del peligro comunista. A esta película se une la ya referida Morir en España, film de una agresividad manifiesta, realizado como respuesta al documental de Fréderic Rossif, Morir en Madrid.

Contra toda lógica, ambas obras se empeñan en resucitar la «cruzada» contra "el alzamiento rojo para la implantación del soviet en España» (Franco ese hombre) y los "sin dios» que "enseñaban a odiar a Cristo y adorar a Stalin" (Morir en España), connotaciones que, por otra parte, se habían ido suavizando con el llamado cine de reconciliación nacional ${ }^{72}$. Pero todo discurso que se pudiera haber realizado en este último sentido quedó superado por Morir en España. Por mucho que se empeñasen en presentarla como «un relato realista y sincero del mapa nacional desde un punto de partida que llevó a la patria por modo inevitable a planteamientos primero, de áspero sacrificio, para dar después en las hermosas realidades que gozamos ${ }^{73}$, lo cierto es que su desmesura llegó al extremo ridículo de afirmar que «un torero, Victoriano de La Serna, se dejaría coger de un toro al grito de Viva España, mientras el público llamaba cobardes a los diestros españoles, y vociferaba vivas a México y a Rusia», lo que no le impidió ser declarada película de "Especial Interés» por la Dirección General de Cinematografía y Teatro. Los XXV años de paz seguían siendo en el cine XXV años de la "victoria contra el comunismo", reflejando la absoluta contradicción de un régimen que, por estas fechas, se había presentado como garante de la paz y reconciliación de los españoles.

Esa contradicción es la que pone de manifiesto Carlos Saura en La Caza, parábola sobre la Guerra Civil cargada de una violencia extrema, que es, a la vez, un documento sobre la memoria de la misma presente en la España de los años de la modernización ${ }^{74}$. En ello entramos.

72. Se trata de una serie de producciones que se realizan desde mediados de los cincuenta entre las que destaca La fiel infantería (Pedro Lazaga, 1959), en cuyo final, tras una batalla en la que quedaban mezclados los cadáveres de los combatientes de ambos bandos, se hace una dedicatoria tan interesada como sesgada: «A todos los españoles que hicieron esta guerra, estén donde estén, vivos o muertos, jlarga paz!».

73. Crítica firmada por GARCíA EsPÁ, Gabriel, $A B C, 16$ de junio de 1965, p. 105.

74. CAMPORESI, Valeria, "Ya son hechos muy lejanos y es muy difícil recordarlos: La caza (C. Saura, 1965) y la memoria cinematográfica de la guerra civil durante el franquismo», en DE PABLO, Santiago (ed.), La historia a través del cine. Europa del este y la caída del muro. El franquismo, Universidad del País Vasco, 2000, pp. 97-107, p. 98. 
Lo primero que debemos destacar de La caza es la violencia latente en el desarrollo de toda la película, una violencia que, potenciada por un clima cada vez más asfixiante, sólo necesita de una excusa para terminar estallando entre los miembros del grupo. Se trata de cuatro amigos -tres de ellos excombatientes de la Guerra Civil- que se reúnen para efectuar una partida de caza en una reserva toledana. Conforme avanza la jornada, y consecuencia de una creciente tensión entre los mismos, acaban matándose entre sí, al encontrar en la violencia el único medio válido para «resolver» sus diferencias. De esta forma, si la violencia contra el otro había servido en el pasado para reforzar los vínculos dentro del grupo, ahora se vuelve contra el mismo, significando su autodestrucción ${ }^{75}$.

A la matanza sólo sobrevivirá Enrique (Emilio Gutiérrez Cava), joven que pertenece a otra generación y que asiste atónito al desarrollo de una tragedia que no comprende, como tampoco sabe nada de una guerra con nombre propio, siempre presente en la película y apenas mencionada por la criba de la censura ${ }^{76}$.

Se puede pensar que Saura no sólo hablaba de la Guerra Civil, sino del momento actual de un régimen que nunca renunció a la violencia como forma de sostén político. Así lo supo ver Pier Paolo Pasolini, miembro del jurado que otorgó el Oso de Plata al mejor director en el Festival de Berlín, por «la valentía e indignación con que presenta una situación humana característica de su tiempo y de su sociedad ${ }^{77}$.

El director aragonés denunciaba, de esta forma, la pomposidad con la que el régimen de Franco se presentaba como garante de una paz que había permitido la reconciliación sincera entre los españoles. Para Saura, en cambio, las heridas continuaban abiertas en un cuerpo social representado por tres excombatientes, que seguían utilizando la violencia de las armas en su papel de cazadores. Como ha indicado Manuel Delgado, es fácil reconocer en la metáfora del cazador la figura del soldado ${ }^{78}$.

Hay una secuencia fundamental en la que se expresa claramente esta metáfora, interpelando, además, al espectador mediante una sucesión de miradas-cámara de los protagonistas. En la misma, tres de los cuatro «amigos» comienzan

75. Ver el comentario que, en este sentido, hace DeLGADO RUIZ, Manuel, «Confini labili: la guerra civile tra individuo e società», en RANZATO, Gabriele, Guerre fratricide... op. cit., pp. 129-156.

76. De todas formas, los censores no veían mucho peligro en una película destinada a minorías, por lo que informaban que: «tiene una gran carga y enorme mala intención, pero no veo motivo de prohibición, pues no creo que mucha gente entienda la mala idea que tiene». Citado por ARAGUEZ RUBIO, Carlos, «La política cinematográfica española en los años sesenta: la propaganda del régimen a través del nuevo cine español (1962-1967)", op. cit., p. 84. Por otra parte, no es difícil entender la falta de fe en un público que, como indicara Enrique Monterde, "conocía poco menos que de oídas los films de Antonioni, Visconti, Bergman, Bresson, Dreyer, Mizoguchi o Buñuel», en Heredero, Carlos F., y MONTERDE, José Enrique (eds.) Los "nuevos cines» en España, op. cit., "Introducción», p. 13.

77. Citado por GUBERN, Román, 1936-1939: La guerra de España en la pantalla, op. cit., p. 155.

78. DelGADO RuIZ, Manuel, "Confini labili: la guerra civile tra individuo e società», op. cit., p. 131. 
hablando de caza para terminar enredados en la confusión de una conversación en la que se refleja la experiencia vital que marcó sus vidas:

Luis: «Para el buen cazador la caza del conejo no tiene ningún interés. Un bicho inofensivo que lo único que intenta es esconderse».

Paco: «Los débiles no tienen nada que hacer en la vida, ni los débiles ni los tarados, es una ley de la naturaleza».

Enrique: «¿no lo dirás en serio?».

José: "En lo de la caza tiene razón Luis, al conejo se le dan pocas oportunidades para defenderse, cuantas más defensas tiene el enemigo más bonita es la caza, se lucha de poder a poder».

Luis: «Por eso alguien dijo que la mejor caza es la caza del hombre».

Y más adelante:

José: «De acuerdo entonces, vamos más adelantados Paco y yo, después Enrique a la derecha y tú cerrando la mano por la izquierda».

Luis: «Oye, que esto no es una operación militar».

De ahí también la importancia dada al paisaje, antiguo escenario de batallas donde los cráteres abiertos actúan a modo de cicatrices de un pasado del que el presente sigue siendo consecuencia: "Aquí murió mucha gente, a montones murieron aquí y ahora sólo quedan los agujeros, buen lugar para matar». Todo queda sintetizado en la escena de la siesta, en la que la cámara, como ha indicado Santos Zunzunegui, acaba igualando "la geografía de la carne con la del paisaje» ${ }^{79}$.

Esa guerra, que ha quedado sedimentada en el paisaje y registrada en la memoria de los protagonistas, aparece también como un fantasma que planea sobre la identidad moral de otra generación, de ahí que Enrique afirme:

«Tengo la impresión de haber estado aquí otras veces. Me gusta, el calor, el olor del tomillo. ¡Qué sensación más extraña! ¿Cuándo he estado yo en un sitio como éste?».

Y, más adelante, cuando salga a colación el esqueleto de la Guerra Civil que José esconde en una cueva, pregunte, para intentar comprender la naturaleza de unos restos sin identidad, "¿Qué guerra?", a lo que obtiene como respuesta: "A ti qué más te da». Desde este momento cinematográfico, esta generación buscará insistentemente una respuesta alternativa.

\section{2}

Se trata de una generación que trata de recuperar un pasado que marcó indeleblemente su niñez, proyectando una mirada alternativa a la omnipresente del poder. Como nos dice la voz en off de Canciones para después de una guerra:

"Las cosas no eran como eran. Quizás no sean ahora tampoco como son. Da igual. Pero existieron, tuvieron que existir, porque las recordamos».

79. ZunZUnEGUI, Santos, «La caza (Carlos Saura, 1965) Mirada distante, mirada cercana», en HeREDERO, Carlos F., y MONTERDE, José Enrique, Los «nuevos cines» en España. Ilusiones y desencantos de los años sesenta, Valencia, Ediciones de la Filmoteca, 2003, pp. 415-417. 
Basilio Martí Patino había nacido en 1930, Carlos Saura en 1932, Jaime Camino en 1936, Víctor Erice en 1940. Es decir, se trata de una generación que supuestamente había nacido para crecer en democracia y que, sin embargo, tuvo que vivir el franquismo, que como ese fantasma del monstruo de Frankenstein que nos muestra Erice, les perseguirá obsesivamente, siempre presente en la ausencia de un futuro todavía por construir ${ }^{80}$. Testigos silenciosos de la tragedia de la guerra, impedidos, maniatados durante los años de su formación por un régimen inmovilista, estos directores representan a la perfección el papel que jugaban los niños en el Neorrealismo italiano. Así, Guilles Deleuze supo ver cómo esa impotencia motriz de los niños para actuar en un mundo de adultos, la suplían potenciando su capacidad de mirar ${ }^{81}$.

Se trata de una mirada que dirigirán al pasado, intentando desvelar los orígenes de una identidad que necesariamente debía pasar por el diálogo intergeneracional, para recuperar una memoria colectiva de la que no habían podido participar. No se trataba tanto de perder una memoria, como la generación de los testigos, sumidos en el olvido, sino de no haber tenido acceso a la misma. Es esto ante lo que se rebelará esta nueva generación que, consciente de la artificialidad mítica de la memoria impuesta, tratará de reconstruir la suya propia, para recuperar la «memoria negada» 82 .

Pero se tratará en todo momento de un empeño personal, de miradas individuales que buscan su propia identidad y que, carentes de vectores sociales que ayuden a conjugar una memoria colectiva y moviéndose en el terreno de la metáfora, se muestran incapaces de ir más allá de flashes confusos del recuerdo, donde el tiempo presente se confunde de forma fantasmática con el pasado, comprobando hasta qué punto pesa en ellos la experiencia traumática de una guerra vivida en la más tierna infancia.

Así, vemos como pasado y presente se confunden en la atormentada memoria de Luis, el protagonista de La prima angélica (Carlos Saura, 1973), que es interpretado, tanto en su edad adulta como infantil, por José Luis López Vázquez.

Por eso Saura no recurre al flashback a efectos de rememoración del pasado, con lo que resalta que no se trata de una vuelta instrumental para interrogarlo (es decir, traer el pasado al presente), sino que el pasado se impone continuamente a la voluntad del sujeto, sin elección posible. La escena definitiva es la final, cuando Luis es capaz de discernir la diferencia entre pasado y presente, comprobando que la historia de amor con su prima es imposible (ella ahora es

80. El propio Saura declaraba que la guerra había tenido una influencia decisiva tanto para los que la vivieron como niños como para los que nacieron después, que sufrían igual las «consecuencias de todo un sistema político, de todo un sistema represivo de educación, pero también de conflictos personales, de pérdidas familiares». Citado por GUBERN, Román, 1936-1939: La guerra de España en la pantalla, op. cit., p. 158.

81. DeleuZe, Gilles, La imagen-tiempo. Estudios sobre cine 2, Barcelona, Paidós, 1996, p. 14.

82. TORREL, Joseph, "Para ignorarnos menos. La reconsideración del pasado durante la transición", Cuadernos de la Academia, n. ${ }^{\circ} 6$ (1999), pp. 79-90, p. 80. 
una mujer casada) y decide marcharse para no volver. Sin embargo, cuando está cargando las maletas en el coche que lo alejará de ese pasado, se encuentra con la hija de su prima, con la que decide dar un paseo en bicicleta, hasta que ambos son detenidos por unos soldados franquistas: estamos nuevamente en 1936. El pasado, sin ser evocado voluntariamente, vuelve a apoderarse del presente, en una espiral de la que el protagonista no puede escapar. De esta forma, la función última de la memoria como proceso de identidad queda anulada: "conservar sin elegir no es una labor de la memoria», ha escrito Todorov ${ }^{83}$.

Por lo tanto, la memoria individual, incapaz de actuar activamente en el presente, termina mostrándose insuficiente:

"Y otra vez el silencio. Sólo consigo recordar aquellas canciones acordándome del silencio, un silencio lejano, fuerte, oscuro como las noches sin dormir, o como el hambre, o como tanto callar. Blanco y negro, blanco y negro sí, como mi destrozada e inútil memoria» ${ }^{84}$.

Hay, al mismo tiempo, todo un abismo entre el presente y la Guerra Civil, que hace ininteligibles ambos períodos para el protagonista, un auténtico agujero negro que imposibilita la construcción de la identidad en ese presente paralizado que en muchos aspectos supuso el franquismo.

De esta forma, en otras ocasiones el protagonista no ha perdido la memoria, sino que carece de ella, imposibilitado por un silencio que impide el diálogo intergeneracional. En este sentido, hay en estas representaciones algo que separa irremediablemente a los «hijos de la guerra» de sus padres, a los que son incapaces de comprender como podemos ver en dos películas ejemplares: El espíritu de la colmena y El sur, de Víctor Erice. En ambas obras la figura del padre aparece a los ojos de las niñas como algo fantasmal y enigmático, portador de un silencio que es guardián de un pasado traumático y que estéticamente queda reflejado en la continua presencia de espacios lúgubres y opresivos, detentadores de un nivel global de incomunicación ${ }^{85}$.

Ese "limbo» a donde van los que carecen de memoria es en el que queda sumergida Ana (Ana Torrent), la protagonista de El espiritu de la colmena, tras no encontrar respuestas satisfactorias a las insistentes preguntas con las que pretende comprender ese otro mundo posible -más allá de la realidad cotidiana- que le ha mostrado el cinematógrafo.

Caso distinto es el de Estrella (Icíar Bollaín) en El Sur. Cuando, ya adolescente, es convocada por su padre (Omero Antonutti), quizás dispuesto a dar respuesta a todos los enigmas con los que ésta creció, una distancia insalvable se vuelve a interponer entre ellos: La del olvido. Así, cuando por fin padre e hija comienzan a hablar sobre la falta de entendimiento, la conversación es interrumpida por los compases de un pasodoble que suena de fondo: En er mundo,

83. TODOROv, Tzvetan, Memoria del mal tentación del bien, op. cit., p. 155.

84. De la voz en off de Canciones para después de una guerra.

85. Ver BALLESTEROS, Isolina, "Las niñas del cine español: La evasión infantil en El espíritu de la colmena, El sur y Los años oscuros", Revista Hispánica Moderna, 49, diciembre de 1996, pp. 232-242. 
ese pasodoble que juntos bailaron en la primera comunión de Estrella, ante una mesa presidida simbólicamente por una clara alegoría de la II República. Sin embargo, Estrella ya no lo recuerda y la comunicación intergeneracional se hace definitivamente imposible. Ella decide marcharse en ese momento, sin atender la petición de su padre, que le sugiere que se quede para conversar un poco más. Desde el final de la sala, Estrella vuelve la mirada para saludarlo por última vez, mientras sigue sonando un pasodoble que no podrán volver a bailar. Agustín se suicidará a la mañana siguiente.

$\mathrm{Si}$ ambas películas suponen intentos de dar respuesta a ese enigma irresuelto que había abierto Carlos Saura en La caza con su pregunta, las soluciones serán distintas. Ana tomará el camino de la huida interior, cayendo en el absoluto mutismo. En la escena final nos es mostrada como un personaje reducido a puro mirar. Nos queda su mirada, una mirada que intenta abrir, mediante la indagación imaginativa, nuevos caminos que la conduzcan a otra realidad.

Por el contrario, la nostalgia por la muerte de su padre actuará a modo de catalizador para que Estrella emprenda definitivamente el camino de la recuperación de su memoria:

"Le dejé allí, sentado junto a la ventana, escuchando aquel viejo pasodoble, sólo, abandonado a su suerte. ¿Pude hacer por él más que lo que en ese momento hice? Es lo que siempre me he preguntado, porque esa fue la última vez que hablé con él».

La respuesta está en el sur, pero en ese momento finaliza la película, con la maleta preparada para partir, mostrando un camino que todavía hay que recorrer.

Son obras, por lo tanto, de construcción de una identidad todavía por resolver. Una identidad que en 1973 estaba buscando caminos alternativos y que diez años después los había encontrado. Sin embargo, el recorrido hacia la memoria será largo todavía, la forma de realizarlo se convierte en el nuevo enigma.

En este sentido, con la muerte del dictador, los años de la transición democrática van a suponer la conquista de un nuevo espacio para los cineastas en su posibilidad de mirar al pasado, y así lo hicieron. Prueba de ello fue el impulso inicial dado por documentales como La vieja memoria (1977), de Jaime Camino, ¿Por qué perdimos la guerra? (1978), de Diego Santillán y Luis Galiardo, así como Caudillo (1977) de Basilio Martín Patino y Raza, el espíritu de Franco (1977), de Gonzalo Herralde. Se trata de películas de montaje centradas abiertamente en la recuperación de la memoria histórica, incluyendo el testimonio de figuras políticas de la época, y en desmontar las «falsas verdades» con las que el régimen franquista se había auto-representado durante cuarenta años.

Por lo tanto, hay una serie de películas realizadas por esta segunda generación, que van a matizar el supuesto "pacto de silencio» realizado durante la Transición ${ }^{86}$. Al margen del mismo, la sociedad comenzó a mirar al pasado,

86. Dejemos claro que se trató de un acuerdo entre los representantes políticos para no instrumentalizar políticamente el pasado. Ver AGUILAR, Paloma, "Guerra civil, franquismo y democracia», Claves de Razón Práctica, n. ${ }^{\circ}$ 140, marzo de 2004, pp. 24-53. 
pese a la falta de vías a partir de las cuales estructurar la recuperación pública de la memoria histórica, ausente en las políticas de Estado ${ }^{87}$. Por lo tanto, estos documentales actuaron como memoria alternativa no sólo a la edificada durante cuarenta años de dictadura, sino también al silencio gubernamental.

Pero, al hilo de esta argumentación, otra pregunta se nos antoja necesaria. Pese a la cantidad de películas sobre la Guerra Civil y el franquismo realizadas en nuestra democracia, sin duda el período histórico más visitado por nuestros cineastas, sólo dos tuvieron la suficiente repercusión como para despertar un debate público: Las largas vacaciones del 36 (Jaime Camino, 1976) y Libertarias (Vicente Aranda, 1995) ${ }^{88}$. Por lo tanto ¿Qué ha pasado en ese arco de veinte años? ¿Por qué esos nuevos espacios de libertad no se tradujeron en una recuperación pública del pasado? ¿Acaso no se habrá dejado sentir en este cine la verdadera naturaleza del tan recurrido pacto de silencio? En este sentido, no es que el cine de los años ochenta y noventa no mirase el pasado, la cuestión es si estas películas se abordaron planteando una adecuada reflexión sobre el mismo en sus inevitables relaciones con el presente ${ }^{89}$.

\section{FIN DE SIGLO: LA REPARACIÓN DE LA MEMORIA}

Contestando a la pregunta con la que cerrábamos el epígrafe anterior, la conquista de nuevos espacios de libertad va a suponer, al tiempo que una recuperación del pasado, la decadencia natural de un cine metafórico que era consecuencia directa de la falta de libertad de expresión. Se inaugura, de esta forma, lo que Enrique Monterde ha llamado «tercera vía» en torno al tema de la Guerra Civil, que suponía un modelo alternativo al subproducto franquista y al culto film metafórico, encaminado a la conquista del mercado que supone el gran público ${ }^{90}$.

Y ahí está la gran paradoja inaugurada por Las largas vacaciones del 36, ya que la conquista del público se va a convertir, al mismo tiempo, en la «expulsión del espectador» de unas salas de cine a las que ya no asistirá para establecer una relación hermenéutica capaz de conducir a un diálogo conjunto con el pasado. En su lugar, el espectador será testigo de una historia carente de matices y con-

87. Así lo reconoció el que fuera Presidente del Gobierno entre 1983 y 1996. Ver GonZÁLEZ, Felipe y CeBrián, Juan Luis, El futuro no es lo que era, Madrid, Punto de Lectura, 2002, pp. 45-46.

88. CRUSElls, Magí, La Guerra Civil española: cine y propaganda, op. cit., p. 216.

89. Ver el artículo de Losilla, Carlos, "Tan lejos, tan cerca: la representación de la historia y la historia como representación en el cine español de los años ochenta y noventa", Cuadernos de la Academia, n. ${ }^{\circ}$ 6, op. cit., pp. 117-126. Sobre el significado del «pacto de silencio» durante la Transición, ver Julié, Santos, "Echar al olvido. Memoria y amnistía durante la transición», Claves de Razón Práctica, n. ${ }^{\circ} 129$, enero-febrero de 2003, pp. 14-24. El autor defiende que dicho pacto no se basó en el olvido sino en todo lo contrario, el recuerdo de la Guerra Civil fue lo que posibilitó «echar voluntariamente al olvido» la memoria de un pasado que no debía estar presente en el debate político: "La cuestión, por tanto, no es que no se haya hablado de todo eso, sino cómo se ha hablado y con qué intención».

90. MONTERDE, José Enrique, "La transición cinematográfica española», Seqüències d'un centerani, d'humanitats, n. ${ }^{\circ} 1$ (1995), pp. 101-112. 
tradicciones, auspiciado por «una ficción que no deja lugar a nada más, que lo relega todo". Ahora es el presente el que absolutamente ha invadido un pasado, "sin posibilidad de conservar rasgo alguno del pasado que fue» ${ }^{91}$.

Tendremos que esperar a Tierra y Libertad y Soldados de Salamina, con sus aciertos y errores, para volver a establecer ese diálogo con el pasado, que pasa por la recuperación de la memoria de las víctimas. En este sentido, ambas películas suponen una reflexión sobre la necesidad de memoria, pero -y esto es lo importante- en clave de reparación, como una necesidad de la democracia.

De ahí que ambas películas enfoquen el diálogo con el pasado en clave intergeneracional ${ }^{12}$. Entra en escena así una nueva generación que ni ha vivido la Guerra Civil ni el franquismo y que cuestiona la forma en la que se había mirado al pasado desde la transición democrática. Se trata de una generación -la de los «nietos de la guerra»-, que es consciente de la propia historicidad de la memoria histórica, que no es una cosa dada, sino que se construye en cada período histórico, abarcando su sentido y $\operatorname{contenidos}^{93}$. De esta forma, desde su toma de conciencia como responsable de la administración de su legado, acomete decididamente la necesaria reparación.

Tierra y Libertad se inicia con la muerte de un exbrigadista en la Europa de los años noventa. Su nieta, ante el total desconocimiento del pasado de su abuelo, comenzará a interesarse sobre el mismo, reconstruyendo su memoria hasta tomar conciencia. Es lo que observamos en la escena final, cuando, puño en alto, canta La Internacional mientras arroja sobre la tumba de su abuelo los restos de la tierra otrora colectivizada. Con este gesto, Loach denuncia la falta de memoria histórica, además de reivindicar el lugar central que debe jugar la ideología en la organización de las sociedades.

Ante las críticas al contenido respecto a la fidelidad histórica con la que Loach afronta su película, el maniqueísmo con el que aborda temas complejos o la excesiva carga de romanticismo en su visión de la historia, hay que decir -con autores como Marc Ferro o Pierre Sorlin-, que una película histórica tan sólo es una transcripción fílmica de una visión de la Historia. Hemos observado cómo el cine de propaganda monta un discurso, una narración o relato de los acontecimientos con la que pretende legitimar ciertas posiciones en el presente, falsificando la Historia en beneficio de unos intereses concretos. Por contra, el cine de autor, como es el caso de Loach, deja claro que se trata de una interpretación del pasado de la que el cineasta ha tomado partido y, por lo tanto, sujeta a crítica, pues no esconde que se trata de un discurso teórico cargado de significación, realizado, eso sí, con métodos distintos a los del historiador. Es

91. LosiLla, Carlos, «Tan lejos, tan cerca: la representación...», op. cit., p. 122.

92. Ver el trabajo de BALleSteros, Isolina, "La exhumación de la memoria histórica: nostalgia y utopía en Soldados de Salamina", Film-Historia, vol. XV, n. ${ }^{\circ} 1$ (2005).

93. Aróstegui, Julio, "Retos de la memoria y trabajos de la historia», Pasado y Memoria. Revista de Historia Contemporánea, n. ${ }^{\circ} 3$ (2004), pp. 15-36. 
decir, una película no es un libro de historia -por lo que no le debemos pedir lo mismo- aunque sí un lugar de reflexión y memoria ${ }^{94}$.

Este diálogo intergeneracional como clave de la recuperación de la memoria histórica iniciado por Tierra y Libertad, es retomado años más tarde en Soldados de Salamina, enésima prueba del lugar central que ocupa la recuperación de la memoria histórica en nuestra cultura contemporánea. Una recuperación de la memoria que, al hilo de lo que comentábamos al principio, tiene como sujeto, no a los «héroes» de la resistencia, sino a las víctimas anónimas. Como dice el supuesto héroe que busca la protagonista: «los héroes no sobreviven». Están todos muertos, fueron y continúan siendo víctimas porque: "nadie los recuerda y nunca ninguna calle miserable, de ningún pueblo miserable, de ninguna mierda de país llevará su nombre».

Como tampoco eran héroes los fallecidos en el bando franquista, tal y como habían sido considerados durante cuarenta años, cuando el "culto a los caídos» fue un elemento fundamental de la parafernalia nacionalista ${ }^{95}$. Esta memoria oficial, que trataba de legitimar la guerra y el sacrificio mediante la ritualización mítica de la experiencia, contrasta con esos muertos que son fusilados sin ningún tipo de heroicidad, porque no hay heroicidad en la muerte sino sólo suciedad, barro, horror y sangre, como vemos en el travelling inicial sobre los fusilados en el Collell. Sin embargo, esta referencia al fusilamiento masivo, como al monumento conmemorativo que visita la protagonista, provoca inevitablemente la denuncia definitiva del absoluto silencio y olvido con el que se ha tratado a las otras víctimas que, a diferencia de las "nacionales», todavía hoy siguen enterradas en fosas comunes y cunetas, a setenta años de los acontecimientos.

Si bien, como nos sugiere Soldados de Salamina, todas las víctimas son iguales, las razones en la lucha no son moralmente las mismas. Es el precio que ha pagado la recuperación de la memoria, en beneficio de ese lugar central que ocupan las víctimas anónimas: La despolitización, circunstancia que ya se había dado en la representación cinematográfica de la Segunda Guerra Mundial. Ésta es la gran diferencia entre Soldados de Salamina y Tierra y Libertad, que, como

94. MONTERO, Julio, «Fotogramas de papel y libros de celuloide: El cine y los historiadores. Algunas consideraciones", Historia Contemporánea, 22 (2001), pp. 29-66. La virtualidad del cine como lugar de memoria capaz de promover la reflexión sobre el pasado fue puesta de manifiesto por Jorge Semprún en su defensa de La vita è bella (Roberto Benigni, 1997) como vehículo de transmisión de la memoria de la Shoah. En este sentido, las diferentes exigencias que les debemos hacer a la historiografía, una forma científica de construcción y transmisión del conocimiento, y la ficción cinematográfica, quedan claramente expuestas en el comentario del superviviente de Buchelwald: «Se vogliamo guardare questo film pensando di trarne qualcosa sulla verità dei campi, c'è da spaccare le poltrone. Ma a me interessa sapere cosa può un giovane ricavare come presa di coscienza da quello che fu la Shoah", Corriere della sera, 25 de octubre de 1998.

95. Una aproximación desde la historia local, en PAYÁ LÓPEZ, Pedro, "Violencia, legitimidad y poder local. La construcción simbólica de la dictadura franquista en una comarca alicantina. El Vinalopó Medio, 1939-1948", Pasado y Memoria. Revista de Historia Contemporánea, n. 1 (2002), pp. 197-222. 
dijimos, respondía más a la posición particular de su director, nacido, por otra parte, en 1936.

Esta despolitización, que es reflejo de una época «que no quiere debates políticos sino de ejemplaridad humana ${ }^{96}$, queda claramente ejemplificada en una de las respuestas que da Miralles (Joan Dalmau), en su conversación final con Lola Cercas (Ariadna Gil): "QQué cree usted que pensó?»" (en referencia al soldado que pudo matar a Sánchez Mazas y no lo hizo), a lo que responde: «nada», dando prioridad a la acción personal sobre la política o ideológica ${ }^{97}$.

No debemos interpretar esta repuesta como una negación a la opción política que representaba el bando republicano, la legalidad de la España democrática: "Nunca nadie me ha dado las gracias por dejarme la juventud peleando por su país». Lo que se denuncia es que se pueda matar gratuitamente en nombre "del bien", resaltando el sin sentido de la ejecución masiva de 48 personas en el Collell. En última instancia, por encima de cualquier ideología está la humanidad, la bondad del ser humano, por decirlo con Vasili Grossman: «Es la bondad particular de un individuo frente a otro, es una bondad sin testigos, pequeña, sin ideología. Se la podría calificar de bondad sin sentido. La bondad de los hombres, al margen del bien religioso o social» ${ }^{98}$.

Una última característica en esta forma de recuperar la memoria del abuelo (o del padre), es que lleva irremediablemente implícita el sello de la nostalgia ${ }^{99}$. De nuevo ésta viene representada por un pasodoble que, a diferencia de lo que ocurría en $E l$ sur, sí vuelven a "bailar» Miralles y Lola Cercas, al actuar como auténtico hilo conductor de la búsqueda y definitiva pista que une a ambos personajes, al son de los compases de Suspiros de España.

En la escena final de la película, Lola Cercas se vuelve mirando a Miralles desde el taxi, a la vez que susurra: "Nos volveremos a ver, claro que sí». Sin embargo, la imagen que se aleja de la presencia de Miralles nos va diciendo lo contrario. Allí queda la figura cada vez más lejana, ya casi espectral, de quien es el último testigo, el último representante de una generación que irremediablemente camina hacia su fin ${ }^{100}$. Es entonces cuande añade: "no me olvidaré de usted, no me olvidaré de usted, no dejaré que se olviden de usted».

96. ARÓstegui, Julio, «Traumas colectivos y memorias generacionales...», op. cit., p. 90.

97. No significa, sin embargo, una condena a la ideología, sino a su instrumentalización para dar cobertura a un crimen, recogiendo el último sentido de la afirmación de Juan Goytisolo en Notre musique: "Matar a un hombre por defender una idea no es defender una idea, es matar a un hombre».

98. Grossman, Vasili, Vida y destino, Galaxia Gutenberg/Círculo de Lectores, 2007, p. 517. No podemos más que celebrar la tardía reedición de semejante testimonio sobre los totalitarismos y la barbarie del siglo XX.

99. BALleSteros, Isolina, «La exhumación de la memoria...», op. cit., p. 11.

100. En una escena paralela, desde otro coche que se aleja, Sánchez Mazas (Ramón Fonseré) grita ostensiblemente a "los amigos del bosque»: «no me olvidaré de vosotros nunca, volveremos a vernos», algo que nunca se produce. Quien tenía en sus manos la versión de la historia oficial, podía decidir quien formaba parte de la misma y quien quedaba definitivamente en el olvido. 
Como escribiera Jorge Semprún refiriéndose a la memoria de la Shoah: "Dentro de meses o años, en un porvenir histórico, en cualquier caso, cercano, ya no habrá memoria personal de los campos. Ya no habrá, muy pronto, testimonios directos, en bruto o elaborados, puesto que ya no habrá testigos». Ante esta inevitable realidad, el escritor y superviviente de Buchenwald aboga por la ficción literaria como forma futura de seguir transmitiendo «la verdad esencial de la experiencia» ${ }^{101}$.

Es tras tomar conciencia de este compromiso, ("a los héroes (víctimas) sólo los premia el recuerdo de los demás»), cuando la escritora, que comenzaba la película ante una página en blanco sin poder trazar una palabra, vuelve a escribir.

En definitiva, el enigma que había quedado abierto en el epígrafe anterior se resuelve con el impulso de una nueva generación, esa primera generación nacida y crecida en democracia por la que suspiraba el viejo y digno profesor de $L a$ lengua de las mariposas, encarnado en la figura de Fernando Fernán-Gómez. Una generación -la de los nietos- que bien mediante la toma de conciencia política, como la nieta del brigadista en Tierra y Libertad, bien mediante el compromiso social ante la necesidad de reparación de las víctimas anónimas, como en Soldados de Salamina, denuncian el olvido y reivindican la necesidad ética de la memoria histórica, conscientes de su responsabilidad ${ }^{102}$.

Exhumar los cadáveres (más de 30.000 según estimaciones de la ARMH), identificarlos y trasladarlos para darles sepultura es una obligación moral de la democracia y una necesidad para las familias cara a la reparación moral de las víctimas. Parece que es necesario de una vez por todas no, "abrir heridas", como reiterada y demagógicamente se insiste desde diversos medios y estamentos sociales y políticos de la derecha, sino cerrarlas, porque como dijera el protagonista de una reciente película sobre la Guerra Civil, mientras desinfecta la herida causada por una espina clavada: "Es el secreto de todas la heridas, si no las limpias bien, cicatrizan mal» ${ }^{103}$.

101. SEMPRÚN, Jorge, La escritura o la vida, Barcelona, Tusquets, 1997, p. 141. La primera cita en «El Holocausto 60 años después», El País Semanal, n. ${ }^{\circ} 1478,23$ de enero de 2005, p. 34.

102. Ver supra, nota núm. 4. Debemos entender, además, esta necesidad de memoria desde un punto de vista ontológico, no como simple recuerdo del pasado, sino como reconocimiento de una parte de la realidad olvidada por la Historia. En este sentido, estaríamos -siguiendo el planteamiento que Theodor Adorno hace en su Dialéctica negativa- ante el replanteamiento de un olvido ontológico que tiene que ver con una forma de conocer que, heredada de la Ilustración, tiende a significar la realidad con lo ascendente y presente, en detrimento de lo ausente (donde anida el sufrimiento como componente también de la realidad). Ver, a este respecto, los comentarios de MATE, Reyes, Por los campos de exterminio, op. cit., pp. 161-172.

103. Se trata del largometraje Iris, dirigido por Rosa Vergés en 2004. 